\title{
Heat Generation in Municipal Solid Waste Landfills
}

\author{
Nazli Yeșiller, A.M.ASCE${ }^{1}$; James L. Hanson, M.ASCE²; and Wei-Lien Liu, S.M.ASCE ${ }^{3}$
}

\begin{abstract}
This study was conducted to investigate thermal aspects of municipal solid waste landfills as a function of operational conditions and climatic region. Spatial and temporal distributions of waste temperatures were determined at four landfills located in North America (Michigan, New Mexico, Alaska, and British Columbia). Temperatures of wastes at shallow depths (extending to 6 to $8 \mathrm{~m}$ depth) and near the edges of a cell (within approximately $20 \mathrm{~m}$ ) conformed to seasonal temperature variations, whereas steady elevated temperatures $\left(23\right.$ to $\left.57^{\circ} \mathrm{C}\right)$ with respect to air and ground temperatures were reached at depth and at central locations. Waste temperatures decreased from the elevated levels near the base of landfills, yet remained higher than ground temperatures. Thermal gradients in the range of approximately -30 to $+22^{\circ} \mathrm{C} / \mathrm{m}$ with average absolute values typically less than $5^{\circ} \mathrm{C} / \mathrm{m}$ were measured within the wastes. Heat content $(H C)$ of wastes was determined as the difference between measured waste mass temperatures and unheated baseline waste temperatures at equivalent depths. Peak $H C$ values ranged from 12.5 to $47.8^{\circ} \mathrm{C}$ day/day. The peak $H C$ s were directly correlated with waste placement rates and initial waste temperatures, and they occurred at a specific average precipitation $(2.3 \mathrm{~mm} /$ day $)$ beyond which further precipitation did not contribute to heat generation. $H C$ was determined to conform to exponential growth and decay curve relationships as a function of climatic and operational conditions. Heat generation was determined based on $H C$ using $1 \mathrm{D}$ heat transfer analysis. The heat generation values ranged from 23 to $77 \mathrm{MJ} / \mathrm{m}^{3}$ without losses and were significantly higher than biochemical prediction models, yet lower than values from incineration analyses. Overall, the highest values for temperatures, gradients, $H C$, and heat generation were observed in Michigan, followed by British Columbia, Alaska, and New Mexico. Integrated analysis of temperature and gas composition data indicated that temperature increases and $H C$ values were greater during anaerobic decomposition than aerobic decomposition. Sustained high temperatures and heat generation occurred in wastes under anaerobic conditions.
\end{abstract}

CE Database subject headings: Landfills; Solid wastes; Municipal wastes; Temperature; Thermal analysis; Thermal energy; Heat transfer; Gas.

\section{Introduction}

Heat, gas, and leachate are the primary byproducts of landfill processes in municipal solid waste (MSW) landfills. Heat is generated as a result of biochemical processes and decomposition of organic components in wastes. Elevated temperatures develop that affect the ongoing biochemical processes and mechanical and hydraulic properties and behavior of the wastes, as well as the engineering properties of liners, covers, and surrounding subgrade soils.

Temperature is considered to affect solid waste decomposition in two ways: short-term effects on reaction rates and longer-term effects on microbial population balance (Hartz et al. 1982). In general, decomposition of wastes increases with increasing temperatures up to limiting values. Optimum temperature ranges for

\footnotetext{
${ }^{1}$ Associate Professor, Dept. of Civil and Environmental Engineering, Wayne State Univ., Detroit, MI 48202.

${ }^{2}$ Assistant Professor, Civil and Environmental Engineering Dept. California Polytechnic State Univ., San Luis Obispo, CA 93407.

${ }^{3}$ Graduate Research Assistant, Dept. of Civil and Environmental Engineering, Wayne State Univ., Detroit, MI 48202.
}

the growth of mesophilic and thermophilic bacteria involved in waste decomposition were identified to be 35 to $40^{\circ} \mathrm{C}$ and 50 to $60^{\circ} \mathrm{C}$, respectively, in laboratory studies (Tchobanoglous et al. 1993; Cecchi et al. 1993). Optimum temperature ranges for maximum gas production from waste decomposition were identified to range between 34 and $41^{\circ} \mathrm{C}$ in laboratory studies, reported in DeWalle (1978), Hartz et al. (1982), and Mata-Alvarez and Martinez-Viturtia (1986). A temperature range of 40 to $45^{\circ} \mathrm{C}$ was identified as the optimum range for gas production at a landfill in England (Rees 1980a,b).

Engineering properties of wastes are also affected by temperature. Settlements increased with increasing temperatures in a laboratory study (Lamothe and Edgers 1994). Increased settlements indicate a potential decrease in shear strength of wastes, which can affect stability of waste slopes. In analogy to soils, hydraulic properties and behavior of wastes are also expected to be affected by temperature. Furthermore, the behavior and a host of engineering properties of soil and geosynthetic liner materials as well as subgrade soils are affected by temperatures, as described by Rowe (1998) and Mitchell (1993).

While various studies have been conducted on generation and distribution of leachate and gas in landfills, analysis of heat generation and temperature distribution has been limited. In general, detailed spatial heat distributions or comprehensive long-term thermal trends are not available for landfills, nor have effects of operational or climatic conditions on heat generation in landfills been investigated. This study was conducted to provide a comprehensive analysis of the thermal regime of MSW landfills, including the variation of temperatures, rate of temperature 
changes, thermal gradients, and heat generation capacity as a function of operational and climatic conditions.

\section{Background}

Spatial variations of temperatures in landfills have been reported in the literature (Dach and Jager 1995; Houi et al. 1997; Yoshida et al. 1997; Rowe 1998; Lefebvre et al. 2000; Koerner 2001; Yesiller and Hanson 2003). Temperatures were similar to seasonal air temperatures at shallow depths, at maximum levels at middle depths, and at elevated (with respect to local air and ground temperatures) yet lower than maximum values near the base of landfills. Rees (1980a) proposed that a waste layer with an approximate thickness of $4 \mathrm{~m}$ would decrease the effects of air temperature on the thermal regime of underlying wastes. The maximum reported temperatures generally varied from approximately 40 to $65^{\circ} \mathrm{C}$ and were observed within the middle one-third depth to over one-half depth of landfills with total waste heights of approximately 20 to $60 \mathrm{~m}$. An exception was reported by Koerner (2001) where low temperatures between 10 and $20^{\circ} \mathrm{C}$ were measured for wastes with a maximum height of nearly $50 \mathrm{~m}$ in the long term (more than 9.5 years). Temperatures up to approximately 30 to over $50^{\circ} \mathrm{C}$ were reported near or at the base of landfills (Dach and Jager 1995; Rowe 1998; Gartung et al. 1999; Yoshida and Rowe 2003), and temperatures in the range of 20 to over $30^{\circ} \mathrm{C}$ were reported for liner systems (Rowe 1998; Koerner 2001; Yesiller and Hanson 2003).

Increasing trends were observed in temperatures of wastes subsequent to placement in landfills. Increases were typically observed within days to a few months of placement. Maximum temperatures were reported for wastes that ranged from less than 1 year up to 8 to 10 years old. Temperatures of wastes started decreasing approximately 10 years after placement. The data provided by Houi et al. (1997) indicated that increases in temperature of wastes were correlated with placement temperature. The temperatures attained in the wastes over a 2-year period were higher for wastes that initially had higher temperatures compared to wastes that initially had lower temperatures. Farquhar and Rovers (1973) indicated that the short-term temperature increase in wastes due to aerobic decomposition was directly correlated with the placement temperature of wastes.

Analyses of variations of temperature with waste decomposition phases were provided for near-surface wastes (Farquhar and Rovers 1973; Zanetti et al. 1997; Lefebvre et al. 2000). Upon waste placement, temperatures increased with time to a peak value in the aerobic phase and then decreased to lower values in the subsequent anaerobic decomposition phase. It is expected that air temperatures affected these measurements, however these effects were generally not fully investigated. In addition, these studies were conducted over short periods (days to a few months). Dach and Jager (1995) stated that maximum landfill temperatures of 60 to $70^{\circ} \mathrm{C}$ and up to $85^{\circ} \mathrm{C}$ were measured in anaerobic and aerobic zones, respectively. Conversely, Yoshida et al. (1997) used numerical analysis to predict that anaerobic decomposition would cause development of high temperatures, and Rowe (1998) attributed high temperatures to anaerobic conditions.

Rowe (1998) provided a comprehensive summary of temperatures in landfills and identified depth of waste, rate of filling, and waste properties as factors that affect waste temperature. Rowe (1998) also indicated that moisture content (leachate mounds) had the most significant effect on heat generation and temperature rise in landfills. High temperatures, in the range of approximately 40 to over $60^{\circ} \mathrm{C}$, were associated with the presence of leachate mounds in landfills at depths of approximately 6 to over $20 \mathrm{~m}$. However, elevated temperatures were also observed in landfills without leachate mounding (Gartung et al. 1999; Lefebvre et al. 2000). Rees (1980b) indicated that high water content (with fully saturated conditions at the base of a landfill) and a density of $1 \mathrm{t} / \mathrm{m}^{3}$ were required for optimum gas generation in temperate climates, but warned that excessive water infiltration could inhibit methanogenesis and cool down the waste mass for a combined adverse effect on gas generation.

The configuration of the sensors or the method of measurement may have affected the results obtained in some of the reported studies (Attal et al. 1992; Townsend et al. 1996; Houi et al. 1997; Zanetti et al. 1997). Placement of sensors in rigid, open tubing may cause gas convection and could result in unrepresentative decomposition conditions and temperature measurements. For one-time sampling events, heat gain or loss may occur during drilling operations or during removal of samples from landfills.

In additional thermal analysis, contour plots of temperatures along vertical and horizontal cross sections in landfills were provided by Gartung et al. (1999) and Lefebvre et al. (2000), respectively. The highest thermal gradients were observed near the top and the lowest gradients near the base of the landfill in vertical profiles, and the highest thermal gradients were observed near the edge and the lowest gradients near the central locations of the landfill in horizontal profiles.

Heat generation potential for wastes was also presented in the literature, including values obtained by theoretical analyses of biochemical decomposition of wastes (Pirt 1978; Rees 1980a; El Fadel et al. 1996; Zanetti et al. 1997; Yoshida and Rowe 2003), values obtained by curve-fitting or back-calculation techniques applied to measured field data (Zanetti el al. 1997; Lefebvre et al. 2000), and values obtained for incineration of wastes (Tchobanoglous et al. 1993; SFOE 2004; Davies 2004; Gibbs 2004). Analyses of heat generation due to decomposition have been reported for the aerobic phase, the anaerobic phase, and total decomposition (Table 1). Heat generation values were reported per mass of glucose; per mole of gas (oxygen or methane) or organic matter (cellulose) converted; and per volume or mass of waste. Some investigators reported rates of heat production, whereas others reported absolute magnitudes. Rates of heat generation were higher for the aerobic phase than the anaerobic phase (Yoshida and Rowe 2003; Pirt 1978). A summary of equivalent heat generation per cubic meter of waste is provided in Table 1 . Values cover a range extending more than 4 orders of magnitude that result from fundamental differences in formulation and the level of uncertainty in the estimated parameters.

\section{Testing Program}

The testing program included an extensive field investigation of temperatures and gas levels in wastes at MSW landfills with varying climatic and operational conditions.

\section{Instrumentation}

Temperature and gas composition data have been obtained using custom-designed sensor arrays, each array consisting of multiple sensors placed along a linear path. The arrays begin at a monitoring station (at the perimeter edge or on the top surface of a cell) and terminate at various points within the waste. Temperature arrays consisted of thermocouple wire placed inside flexible PVC 
Table 1. Heat Generation Potential of Wastes

\begin{tabular}{|c|c|c|c|c|}
\hline References & $\begin{array}{l}\text { Heat generation } \\
\text { reported }\end{array}$ & $\begin{array}{l}\text { Equivalent heat } \\
\text { generation } \\
\left(\mathrm{MJ} / \mathrm{m}^{3}\right)\end{array}$ & $\begin{array}{l}\text { Decomposition } \\
\text { conditions }\end{array}$ & Analysis approach \\
\hline Pirt (1978) & $\begin{array}{c}1,520 \mathrm{kcal} / \mathrm{kg} \text { glucose } \\
\left(6,369 \mathrm{~kJ} / \mathrm{kg}, 1,147 \mathrm{~kJ} / \mathrm{mol}^{-} \mathrm{O}_{2}\right)\end{array}$ & NA & Aerobic & Aerobic digestion of glucose \\
\hline Rees (1980a) & $\begin{array}{c}25.5 \text { to } 1,097 \mathrm{MJ} / \mathrm{m}^{3} \text {-year } \\
{[\text { rate }]}\end{array}$ & NA & $\begin{array}{l}\text { Aerobic, } \\
\text { depending on } \\
\text { water content }\end{array}$ & Aerobic metabolism \\
\hline Lefebvre et al. (2000) & $10 \times 10^{3} \mathrm{~kJ} / \mathrm{m}^{3}$ & 10.0 & Aerobic & Heat accumulation in refuse \\
\hline Yoshida and Rowe (2003) & $460 \mathrm{~kJ} / \mathrm{mol}-\mathrm{O}_{2}$ & $1.61^{\mathrm{a}}$ & Aerobic & $\begin{array}{l}\text { Biological decomposition } \\
\text { (equivalent glucose) }\end{array}$ \\
\hline Yoshida and Rowe (2003) & $4.67 \mathrm{~J} / \mathrm{m}^{3} \mathrm{~s}$ [rate] & NA & Aerobic & $\begin{array}{l}\text { Biological decomposition } \\
\text { (equivalent glucose) }\end{array}$ \\
\hline Pirt (1978) & $\begin{array}{l}0.09 \mathrm{kcal} / \mathrm{kg} \text { glucose } \\
(377 \mathrm{~J} / \mathrm{kg} \text { glucose } \\
\left.68 \mathrm{~J} / \mathrm{mol}^{-}-\mathrm{CH}_{4}\right)\end{array}$ & NA & $\begin{array}{l}\text { Anaerobic } \\
\text { digestion }\end{array}$ & $\begin{array}{l}\text { Complete conversion of } \\
\text { organic fraction to } \mathrm{CO}_{2} \text { and } \mathrm{CH}_{4}\end{array}$ \\
\hline Tchobanoglous et al. (1993) & $\begin{array}{c}5.45 \mathrm{GJ} / \mathrm{t} \\
(5,450 \mathrm{~kJ} / \mathrm{kg})\end{array}$ & $5,450^{\mathrm{b}}$ & Anaerobic & $\begin{array}{l}\text { Complete conversion of } \\
\text { organic fraction to } \mathrm{CO}_{2} \text { and } \mathrm{CH}_{4}\end{array}$ \\
\hline El Fadel et al. (1996) & $\begin{array}{c}244.5 \mathrm{kcal} / \mathrm{mol}-\text { organic } \\
\text { material converted } \\
(755 \mathrm{kcal} / \mathrm{kg} \text { cellulose, } 3,163 \mathrm{~kJ} / \mathrm{kg} \text { cellulose })\end{array}$ & NA & Anaerobic & $\begin{array}{l}\text { Enthalpy of reactants of the } \\
\text { stoichiometric biochemical reaction }\end{array}$ \\
\hline El Fadel et al. (1996) & $\begin{array}{c}61 \mathrm{kcal} / \mathrm{mol}_{-} \mathrm{CH}_{4} \text { produced } \\
\left(256 \mathrm{~kJ} / \mathrm{mol}_{-}-\mathrm{CH}_{4}\right)\end{array}$ & $1.38^{\mathrm{c}}$ & Anaerobic & $\begin{array}{l}\text { Enthalpy of products of the } \\
\text { stoichiometric biochemical reaction }\end{array}$ \\
\hline El Fadel et al. (1996) & $26 \mathrm{kcal} / \mathrm{mol}-\mathrm{CH}_{4}$ produced $\left(109 \mathrm{~kJ} / \mathrm{mol}-\mathrm{CH}_{4}\right)$ & $0.59^{\mathrm{c}}$ & Anaerobic & Stepwise biochemical reactions \\
\hline Zanetti et al. (1997) & $900 \mathrm{~kJ} / \mathrm{Nm}^{3}$ & $180^{\mathrm{c}}$ & Anaerobic & $\begin{array}{l}\text { Enthalpy of products of biochemical } \\
\text { reaction obtained using field data }\end{array}$ \\
\hline Yoshida and Rowe (2003) & $43.5 \mathrm{~kJ} / \mathrm{mol}^{-\mathrm{CH}_{4}}$ & $0.23^{\mathrm{c}}$ & Anaerobic & $\begin{array}{l}\text { Biological decomposition } \\
\text { (equivalent glucose) }\end{array}$ \\
\hline Yoshida and Rowe (2003) & $\begin{array}{l}0.218 \mathrm{~J} / \mathrm{m}^{3} \mathrm{~s} \\
\text { (rate) }\end{array}$ & NA & Anaerobic & $\begin{array}{l}\text { Biological decomposition } \\
\text { (equivalent glucose) }\end{array}$ \\
\hline Tchobanoglous et al. (1993) & $11,600 \mathrm{~kJ} / \mathrm{kg}$ & 11,600 & $\begin{array}{c}\text { Complete } \\
\text { decomposition }\end{array}$ & $\begin{array}{l}\text { Proximate analysis and } \\
\text { calorimetry }\end{array}$ \\
\hline SFOE (2004) & $11,900 \mathrm{~kJ} / \mathrm{kg}$ & 11,900 & $\begin{array}{l}\text { Complete } \\
\text { conversion }\end{array}$ & $\begin{array}{l}\text { Energy released } \\
\text { during combustion }\end{array}$ \\
\hline Davies (2004) & $9,200 \mathrm{~kJ} / \mathrm{kg}$ & 9,200 & $\begin{array}{l}\text { Complete } \\
\text { conversion }\end{array}$ & $\begin{array}{l}\text { Energy released } \\
\text { during combustion }\end{array}$ \\
\hline Gibbs (2004) & $9,500 \mathrm{~kJ} / \mathrm{kg}$ & 9,500 & $\begin{array}{l}\text { Complete } \\
\text { conversion }\end{array}$ & $\begin{array}{l}\text { Energy released } \\
\text { during combustion }\end{array}$ \\
\hline
\end{tabular}

Note : NA=direct conversion not applied as sufficient details related to waste composition and/or timing of processes were not provided in the original reference.

${ }^{\mathrm{a} C a l c u l a t e d}$ assuming a waste porosity $=0.4$, oxygen fraction of gas in waste in as-placed condition $=21 \%$.

${ }^{\mathrm{b}}$ Calculated assuming waste composition provided by USEPA (2003), $\rho_{\text {waste }}=1,000 \mathrm{~kg} / \mathrm{m}^{3}$, molecular fractions outlined in Tchobanoglous et al. (1993).

${ }^{\mathrm{c}}$ Calculated assuming ideal gas law applies, $\rho_{\text {waste }}=1,000 \mathrm{~kg} / \mathrm{m}^{3}$, gas production $=200 \mathrm{~m}^{3}(\mathrm{gas}) / \mathrm{m}^{3}($ waste $)$, gas composition $=60 \% \mathrm{CH}_{4}$.

conduit. Type $\mathrm{K}$ thermocouple wires (nickel alloys, $\mathrm{Ni} \cdot \mathrm{Cr} / \mathrm{Ni} \cdot \mathrm{Mn} \cdot \mathrm{Al}$ ) were used due to their resistance to chemical environments. Gas compositions were measured using custombuilt sensing ports (perforated section tubing with filter housing). Copper tubing was used to deliver gas from the sensor to the monitoring station. A thermocouple sensor and a gas port were placed at each measurement location to obtain concurrent temperature and gas data. Temperature data were collected weekly using a digital thermometer, and gas data were collected monthly using a gas extraction monitor that included an infrared sensor and an electrochemical cell. Thermocouple performance for long arrays was verified prior to field installation at controlled conditions in the laboratory. The gas extraction monitor was calibrated before each field survey. The precision of the measurements was $\pm 0.5^{\circ} \mathrm{C}$ for temperature and $\pm 3 \%$ gas composition (for $\mathrm{CH}_{4}$ and $\mathrm{CO}_{2}$ ) and $\pm 1 \%$ (for $\mathrm{O}_{2}$ ).
Horizontal sensor arrays were used to determine the variations in temperature and gas composition with location at a given depth. These arrays were installed in trenches excavated during waste placement when the wastes reached a certain height. Further wastes were placed over the arrays, resulting in an arrangement where the arrays were both overlain and underlain by waste. Vertical sensor arrays were used to determine the variations in temperature and gas composition with depth at a given location in cells that reached design or near-design depths. These cells were temporarily covered with approximately $1-\mathrm{m}$ thick native soils. Boreholes were drilled through the wastes at specified locations, and sand or gravel at depth and bentonite near the surface were used to fill the annular space around the sensor arrays in the boreholes to prevent convection near the arrays, which can influence the measurements. 


\begin{tabular}{|c|c|c|c|c|}
\hline $\begin{array}{l}\text { Climatic zone and } \\
\text { description }^{\mathrm{a}}\end{array}$ & $\begin{array}{l}\text { Cool temperate zone, } \\
\text { humid continental temperate climate }\end{array}$ & $\begin{array}{c}\text { New Mexico } \\
\text { Warm-temperate } \\
\text { subtropical zone, } \\
\text { semidesert climate }\end{array}$ & $\begin{array}{c}\text { Alaska } \\
\text { Cold temperate boreal } \\
\text { zone, oceanic boreal climate }\end{array}$ & $\begin{array}{l}\text { Cool temperate zone, } \\
\text { woodland oceanic climate }\end{array}$ \\
\hline $\begin{array}{l}\text { Average daily high } \\
\text { temperature }\left({ }^{\circ} \mathrm{C}\right)\end{array}$ & 14.7 & 25.1 & 6.2 & 13.5 \\
\hline $\begin{array}{l}\text { Average daily low } \\
\text { temperature }\left({ }^{\circ} \mathrm{C}\right)\end{array}$ & 5 & 11.2 & -1.5 & 6.1 \\
\hline $\begin{array}{l}\text { Average daily } \\
\text { temperature }\left({ }^{\circ} \mathrm{C}\right)\end{array}$ & 9.8 & 18.2 & 2.3 & 9.9 \\
\hline $\begin{array}{l}\text { Annual normal } \\
\text { precipitation }(\mathrm{mm})\end{array}$ & 835 & 240 & 408 & 1,167 \\
\hline Annual normal snowfall (mm) & 1,046 & 135 & 1,793 & 549 \\
\hline Mean annual earth temperature $\left({ }^{\circ} \mathrm{C}\right)$ & 11.7 & 20 & 6 & 11.5 \\
\hline
\end{tabular}

${ }^{\mathrm{a}}$ Based on Landsberg et al. (1966).

${ }^{\mathrm{b}}$ From NCDC (2004).

${ }^{\mathrm{c}}$ From MSC (2004).

\section{Field Sites}

The study was conducted at four municipal solid waste landfills located in different climatic regions in North America: Michigan, New Mexico, Alaska, and British Columbia. The climate statistics for the sites are summarized in Table 2, and details for operational conditions and instrumentation are presented in Table 3. The facilities located in Michigan, New Mexico, and Alaska are modern landfills with Subtitle D liner systems (barriers and leachate collection systems). The facility in British Columbia contains a base support/liner system and a gravity-flow leachate collection system. Freestanding leachate is observed in the waste mass during periods of high precipitation at this site. The Michigan and British Columbia landfills have gas collection systems, whereas the landfills in New Mexico and Alaska do not.

Temperature and gas data were collected in multiple cells using horizontal and vertical arrays at each landfill (Table 3). The length of horizontal sensor arrays ranged from 163 to $206 \mathrm{~m}$, and the number of sensors on each array ranged from 8 to 9 . The length of vertical sensor arrays ranged from 12 to $46 \mathrm{~m}$, and the number of sensors on each array ranged from 8 to 21 . Horizontal arrays were generally installed in wastes less than 5 years old, whereas vertical arrays were installed in wastes with a wide range of ages from 0 to 22 years. Data from a total of 355 temperature sensors and 238 gas sensors were analyzed and presented for measurement periods up to 5 years in this paper.

\section{Analyses}

\section{Temperature and Gas}

Spatial and temporal variations of temperatures and gas compositions at the sites were investigated, effects of climatic and operational conditions were analyzed, and rates of temperature change were also determined.

\section{Thermal Gradient}

Thermal gradients through vertical profiles of the waste masses were determined using data from the vertical arrays. Localized temperature gradients were determined as the quotient of the temperature difference between two adjacent sensors within a vertical array and the distance between the sensors. These data represent instantaneous gradients as they were calculated using measured temperatures from a single monitoring event. Average instanta-
Table 3. Details of Operational Conditions and Instrumentation at Sites

\begin{tabular}{|c|c|c|c|c|}
\hline Parameter & Michigan & New Mexico & Alaska & $\begin{array}{l}\text { British } \\
\text { Columbia }\end{array}$ \\
\hline $\begin{array}{l}\text { Total site area } \\
\text { (ha) }\end{array}$ & 81 & 194 & 111 & 635 \\
\hline $\begin{array}{l}\text { Design waste } \\
\text { placement area } \\
\text { (ha) }\end{array}$ & 65 & 79 & 67 & 225 \\
\hline $\begin{array}{l}\text { Average waste } \\
\text { intake ( } t \text { /year) }\end{array}$ & 965,000 & 114,000 & 317,000 & 390,000 \\
\hline $\begin{array}{l}\text { Waste placement } \\
\text { rate (m/year) }\end{array}$ & $20-27$ & 4 & $4-7$ & $5-12$ \\
\hline $\begin{array}{l}\text { Design volume } \\
\left(\mathrm{m}^{3}\right)\end{array}$ & $26,240,000$ & $11,754,000$ & $32,360,000$ & $46,000,000$ \\
\hline $\begin{array}{l}\text { Percent design } \\
\text { footprint covered }\end{array}$ & 85 & 17 & 86 & 100 \\
\hline $\begin{array}{l}\text { Percent design } \\
\text { volume filled }\end{array}$ & 60 & 15 & 23 & 52 \\
\hline $\begin{array}{l}\text { Average waste } \\
\text { column height }(\mathrm{m})\end{array}$ & 21.3 & 13.1 & 26.5 & 10.6 \\
\hline $\begin{array}{l}\text { Leachate pumped } \\
\left(\mathrm{m}^{3} / \mathrm{m}^{2} \text {-year }\right)\end{array}$ & 0.063 & 0 & 0.068 & 0.628 \\
\hline $\begin{array}{l}\text { Gas produced } \\
\left(\mathrm{m}^{3} / \text { year }\right)\end{array}$ & 1.23 & $0^{\mathrm{a}}$ & $0.80^{\mathrm{a}, \mathrm{b}}$ & 2.18 \\
\hline Leachate $\mathrm{pH}$ & 7.68 & NA & 4.05 & 7 \\
\hline Leachate COD & 2070 & NA & 340 & 500 \\
\hline Leachate BOD & NA & NA & 310 & 100 \\
\hline $\begin{array}{l}\text { Year site began } \\
\text { accepting waste }\end{array}$ & 1984 & 1996 & 1992 & 1967 \\
\hline $\begin{array}{l}\text { Number of } \\
\text { instrumented cells }\end{array}$ & 5 & 2 & 3 & 6 \\
\hline $\begin{array}{l}\text { Total temperature } \\
\text { sensors }\end{array}$ & 99 & 26 & 111 & 119 \\
\hline Total gas sensors & 68 & 23 & 93 & 54 \\
\hline $\begin{array}{l}\text { Date of first } \\
\text { sensor installation }\end{array}$ & 1999 & 2000 & 2002 & 2003 \\
\hline
\end{tabular}

Note: NA=not available.

${ }^{\mathrm{a}}$ Gas system not installed.

${ }^{b}$ Based on numerical simulation for medium-dry/dry conditions. 


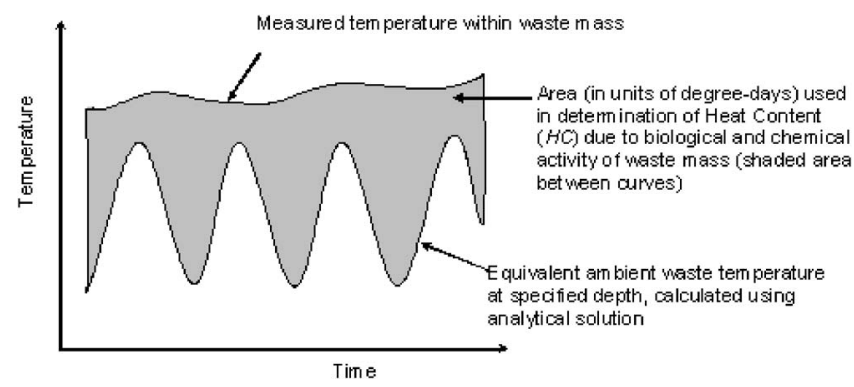

Fig. 1. Determination of $H C$

neous gradients were determined for the entire monitoring period at each site. Positive gradients correspond to downward heat flow based on the sign convention used in the analysis. Absolute gradients were used to quantify magnitudes of heat flow to the full extent (irrespective of flow direction).

\section{Heat Content}

An analysis was conducted to quantify the heat gain in the wastes compared to unheated baseline conditions. Heat content $(H C)$ of the waste mass is defined as the difference between measured waste temperatures and unheated baseline waste temperatures at equivalent depths. The baseline waste temperatures were calculated using the analytical formulation for ground temperature presented in ORNL (1981):

$$
T_{(x, t)}=T_{m}-A_{s} e^{-x \sqrt{\pi / 365 \alpha}} \cos \left[\frac{2 \pi}{365}\left(t-t_{0}-\frac{x}{2} \sqrt{\frac{365}{\pi \alpha}}\right)\right]
$$

where $T_{(x, t)}=$ temperature $\left({ }^{\circ} \mathrm{C}\right)$ at depth $x$ and time $t ; T_{m}=$ mean annual earth temperature $\left({ }^{\circ} \mathrm{C}\right) ; A_{s}=$ amplitude of surface temperature wave $\left({ }^{\circ} \mathrm{C}\right) ; x=$ depth below surface $(\mathrm{m}) ; \alpha=$ thermal diffusivity $\left(\mathrm{m}^{2} /\right.$ day); $t=$ time of year in days (where $0=$ midnight December 31 ); and $t_{0}=$ phase constant (34.6 days).

A thermal diffusivity $(\alpha)$ of $4.3 \times 10^{-2} \mathrm{~m}^{2} /$ day was used to provide baseline values for an equivalent waste mass that was undergoing seasonal temperature variations but was not gaining heat due to decomposition processes. The mean annual earth temperatures are provided in Table 2. The amplitudes of surface temperature waves were $15^{\circ} \mathrm{C}$ for Michigan, New Mexico, and Alaska and $7^{\circ} \mathrm{C}$ for British Columbia.

$H C$ was determined by first calculating the area between the time-temperature curves for the measured waste temperatures and the analytical baseline unheated waste temperatures (Fig. 1). Then the calculated area was divided by the duration of the analysis period to normalize $H C$ with respect to time. The resulting $H C$ had units of degrees centigrade day per day $\left({ }^{\circ} \mathrm{C}\right.$ day/day). This analysis allowed for determination of heat gain in the waste mass due solely to decomposition processes and not due to climatic conditions.

\section{Heat Generation}

Heat generation was estimated using the field data in an analytical heat transfer formulation. The energy required to raise the temperature of waste is dependent on the heat capacity of the waste, the magnitude of temperature increase of the waste, the evaporation of water into the landfill gas phase, the temperature of the biochemical reactions, and the heat loss to the surrounding environment. Heat generation was determined for waste located at the central core of the waste mass at each site. Initially, heat losses to the surrounding environment were assumed to be negligible to provide a conservative estimate based on the relatively high insulating quality of municipal solid waste (Hanson et al. 2000). Heat capacity of wastes was estimated to be $2.0 \mathrm{MJ} / \mathrm{m}^{3} \mathrm{~K}$ for this analysis based on experimental data as well as values reported in the literature (Young 1992; Yoshida and Rowe 2003).

The peak $H C$ for a given site was used as the magnitude of temperature increase of the waste. The evaporation energy and temperature increase due to biochemical reactions were included using the analysis provided by Young (1992). In this formulation, the energy used to heat waste was equal to the total biochemical energy produced by methanogenesis minus the effects of energy used to evaporate water. The energy used to evaporate water into the landfill gas phase is a function of temperature, as the number of moles of water vapor required to saturate each mole of landfill gas increases with temperature. The relationship between temperature and the fraction of total biochemical energy that is used to heat a landfill as presented by Young (1992) was employed in this analysis. The resulting equation for energy production is presented below:

$$
E=\sum_{i=1}^{n} \Delta T_{i} c M(T)_{i}
$$

where $E=$ energy production (heat generation, $\mathrm{MJ} / \mathrm{m}^{3}$ ); $\Delta T_{i}=$ increment of temperature rise for waste $(\mathrm{K}) ; c=$ heat capacity of waste $\left(\mathrm{MJ} / \mathrm{m}^{3} \mathrm{~K}\right)$; and $M(T)_{i}=$ fraction of energy released that is used for heating a landfill. The total temperature increases were subdivided into $10^{\circ} \mathrm{C}$ increments. The incremental $M(T)$ was equal to approximately 0.99 at $10^{\circ} \mathrm{C}$ and 0.56 at $60^{\circ} \mathrm{C}$ (Young 1992). Eq. (2) represents a generalized formulation that is valid for computing heat generation for any $\Delta T$ and is independent of time.

A simplified analysis was conducted to include heat losses in the determination of heat generation. Conductive losses were estimated by a 1D (vertical) heat transfer analysis using a waste thermal conductivity of $1 \mathrm{~W} / \mathrm{mK}$. The magnitudes of the losses were calculated using a thermal gradient from the central core of the landfill (location of maximum $H C$ ) to both the landfill cover (at average annual air temperature) and the subgrade (10 $\mathrm{m}$ below the liner at mean annual earth temperature). Downward losses were also determined to bottom liners at stable elevated temperatures, as obtained from Yesiller and Hanson (2003). Convective thermal losses were estimated by determining the magnitude of heat removed by leachate transport using actual leachate quantities from the sites. The leachate was assumed to enter a cell at a temperature equal to the average daily air temperature and was heated to either elevated liner or peak waste temperatures in the cell. Heat capacity of water was used for leachate in this analysis.

\section{Temperature and Gas Correlations}

An analysis was conducted to determine the amount of temperature increase and the heat generation that occurred during distinct gas generation phases of wastes. Data obtained from horizontal arrays were used to determine temperatures and gas compositions from the onset of waste placement in a cell. The analysis was conducted using data from the Michigan site with the highest number of horizontal arrays. 

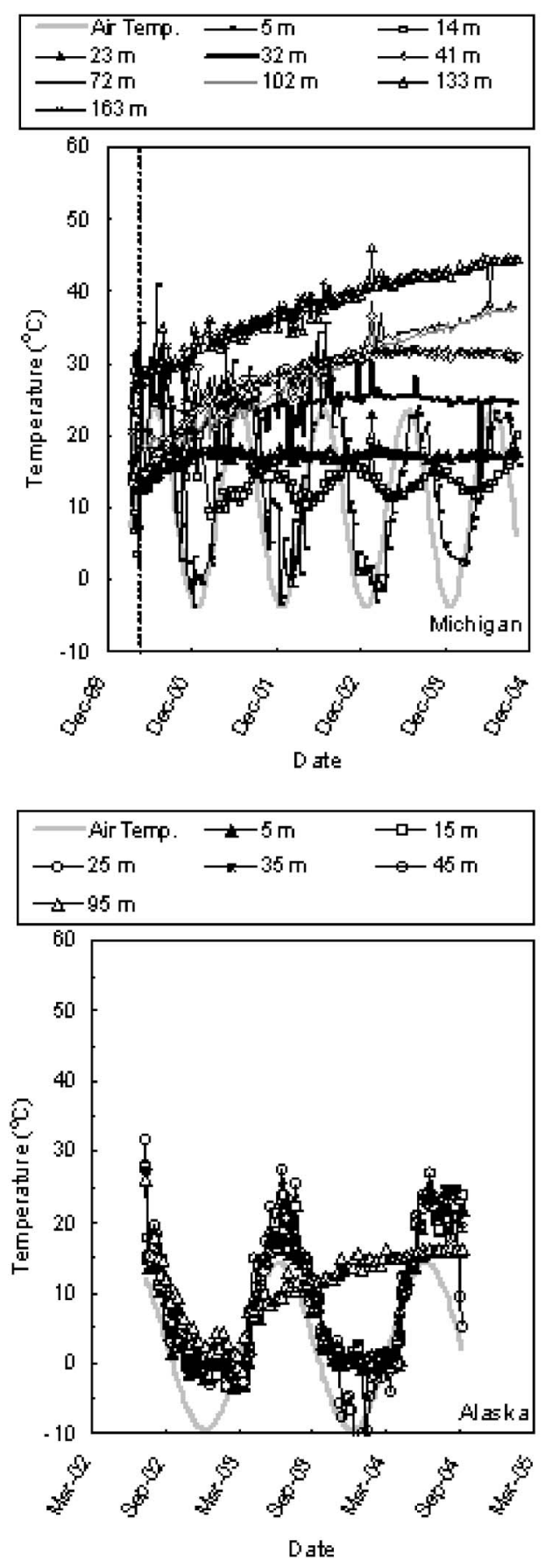
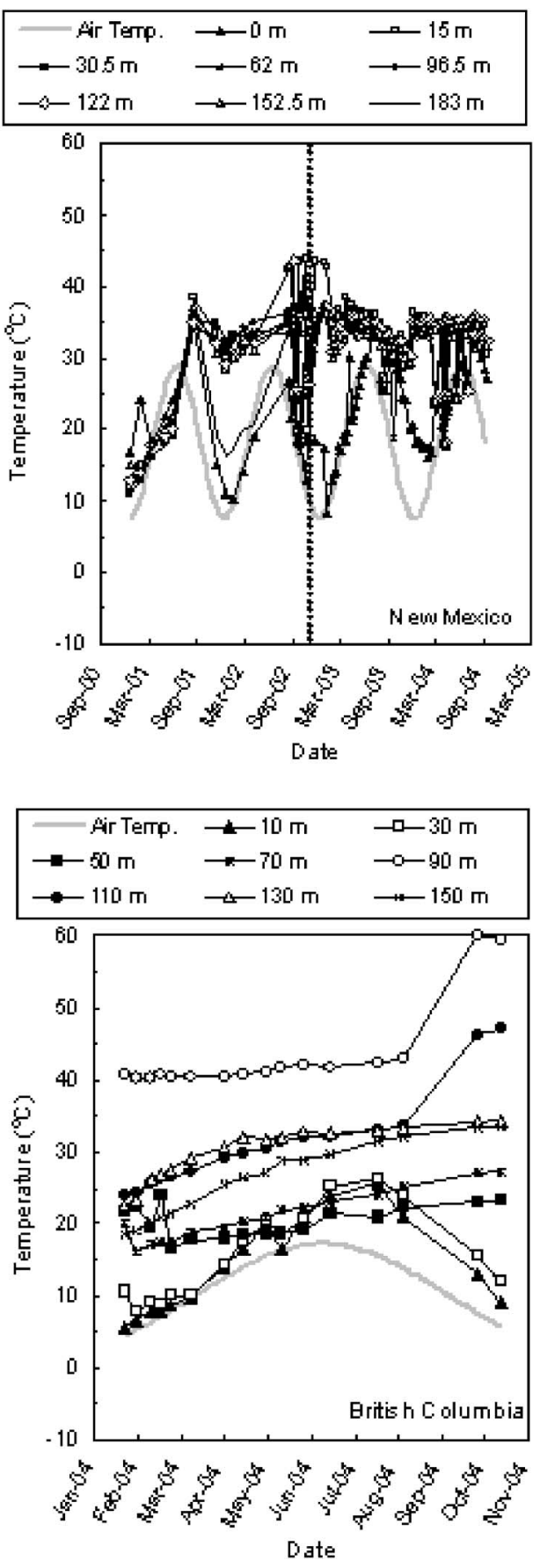

Fig. 2. Typical examples of variation of temperature with length (horizontal arrays)

\section{Results and Discussion}

Initially, the spatial and temporal variations of temperatures and thermal gradients in wastes are presented. Then heat content and heat generation in municipal solid wastes are presented. Finally heat generation is discussed in relation to decomposition conditions at one of the sites using gas data obtained at the site.

\section{Waste Temperature}

Data from horizontal arrays were analyzed to determine the temporal variations in temperature with location at a given depth (Fig. 2). Distance for each sensor in an array away from the edge/surface of a cell is provided in the plots. Air temperatures are presented using sinusoidal representations of measured air temperatures for clarity in the plots. Waste filling dates above the arrays were March 2000-January 2003 (Michigan), October 2002-July 2004 (New Mexico), April-August 2003 (Alaska), and August 2003-present (British Columbia). The start of waste filling periods is marked with vertical dashed lines in the plots. No line is shown for British Columbia as waste filling started prior to the monitoring period. All of the sensors in the arrays were covered with wastes at the Michigan and New Mexico sites, whereas 17 and $75 \%$ of the arrays were covered in the Alaska and British Columbia sites, respectively. The average waste heights over the arrays were $18,8.5,4$, and $5 \mathrm{~m}$ for Michigan, New Mexico, Alaska, and British Columbia, respectively (Fig. 2). The average normalized depths for horizontal arrays were $0.73,0.46,0.33$, and 
Table 4. Maximum Stable Temperatures Measured Using Horizontal Sensor Arrays

\begin{tabular}{|c|c|c|c|c|}
\hline Site & $\begin{array}{l}\text { Maximum } \\
\text { stable } \\
\text { temperature } \\
\left({ }^{\circ} \mathrm{C}\right)\end{array}$ & Waste age & $\begin{array}{c}\text { Normalized } \\
\text { length }^{\mathrm{a}}\end{array}$ & $\begin{array}{c}\text { Normalized } \\
\text { depth }^{\text {b }}\end{array}$ \\
\hline Michigan & 57 & 1 & $0.10^{\mathrm{c}}$ & 0.45 \\
\hline New Mexico & 35 & 3 & 0.50 & 0.66 \\
\hline Alaska & 23 & 2 & 0.58 & 0.11 \\
\hline British Columbia & $42^{\mathrm{d}}$ & 1 & 0.37 & 0.20 \\
\hline
\end{tabular}

${ }^{\mathrm{a}} L_{S} / L_{t}$, where $L_{S}$ is horizontal distance from edge of cell to sensor location and $L_{t}$ is total horizontal length of waste mass at specific elevation of sensor.

${ }^{\mathrm{b}} D_{S} / D_{t}$, where $\mathrm{D}_{S}$ is depth of waste above sensor and $D_{t}$ is total depth of waste mass at location of sensor.

${ }^{\mathrm{c}}$ In this case, $L_{S}$ is equal to $39 \mathrm{~m}$ and $L_{t}$ is equal to $400 \mathrm{~m}$. The low normalized length is due to high total length of cell; while normalized length is low, sensor is still significantly far from edge of cell.

${ }^{\mathrm{d}}$ Higher temperatures than $42^{\circ} \mathrm{C}$ were observed in British Columbia, but these have not yet become stable trends.

0.19 for Michigan, New Mexico, Alaska, and British Columbia, respectively, where the normalized depth is the quotient of the depth of waste above a sensor and the total depth of the waste mass at the location of the sensor.

The variations of temperatures near the edges of cells were similar to seasonal air temperatures with dampened amplitudes, whereas the temperatures near the centers of the cells were relatively steady, demonstrating increasing trends upon waste placement. The seasonal variations in temperatures decreased significantly within approximately $20 \mathrm{~m}$ from the edges of the cells in the landfills. The maximum elevated temperatures obtained by analyzing all of the horizontal sensor arrays at the study sites are presented in Table 4. The highest temperatures were observed at the Michigan landfill, followed by the British Columbia, New Mexico, and Alaska landfills. The high temperatures were generally observed at central regions within wastes along a given horizontal planar cross section at a given depth. The midregion has a horizontal length approximately one-half of the total horizontal length of the waste mass at the given depth. The region for elevated temperatures can be wider for a large cell, as shown for the Michigan site in Table 4.

It was observed that the placement of the first waste layer (waste lift) with a constant depth of 4 to $5 \mathrm{~m}$ significantly reduced the seasonal fluctuations in the temperatures of the wastes except at the edges of a cell. The 4 to $5 \mathrm{~m}$ height represents the typical effective waste lift depths used in North America. Steady temperature trends started to develop in the wastes subsequent to placement of the first overlying lift. The temperatures of new wastes generally increased with time, the increases occurring either at a single rate or at an initial rapid rate followed by a continued yet slower rate. The temperature increased at a single rate of $0.1^{\circ} \mathrm{C}$ /year in New Mexico. Temperatures increased at two separate, successive rates for 40,86 , and $67 \%$ of the data at the sites located in Michigan, Alaska, and British Columbia, respectively. The initial rates of increase varied between 23 and $59^{\circ} \mathrm{C} /$ year, and the subsequent rates of increase varied between 0.6 and $20^{\circ} \mathrm{C} /$ year at these sites. The increases were observed to continue for extended periods (exceeding 5 years at the Michigan site with the longest duration of monitoring) subsequent to waste placement. The long-term temperatures were affected by the initial waste temperatures at time of placement. Somewhat higher initial increases were observed for wastes placed during warm seasons than wastes placed during cold seasons. While the overall long-term temperature increase is similar for waste placement in warm and cold seasons, the magnitudes of temperatures attained are higher for wastes placed during warm seasons than during cold seasons due to the initial high waste temperatures (Fig. 2).

Results from vertical arrays were used to evaluate the variation of temperatures with depth (Fig. 3). Depth of each sensor in an array from the top surface of a cell is provided in the plots. Air temperatures are presented using sinusoidal representations of measured air temperatures for clarity in the plots. The average age of the wastes presented in Fig. 3 were 6.5, 5.5, 2.5, and 7 years for the cells located in the landfills in Michigan, New Mexico, Alaska, and British Columbia, respectively. The total depth of the wastes presented in Fig. 3 were 31, 19, 51, and $19 \mathrm{~m}$ in Michigan, New Mexico, Alaska, and British Columbia, respectively.

The maximum elevated temperatures observed for vertical sensors at the various sites are presented in Table 5. Data from all vertical installations in all of the cells at a given site were analyzed to determine the values reported in Table 5. The highest temperatures were measured at the Michigan landfill, followed by the British Columbia, Alaska, and New Mexico landfills, where the lowest stable waste temperatures were measured. The maximum stable waste temperatures occurred somewhat earlier in British Columbia, with longer periods required for Michigan and New Mexico. The longest period required to reach maximum stable temperatures was observed in Alaska.

The temperatures (magnitude and variation) near the surface were similar to seasonal air temperatures, whereas the temperatures at greater depth were elevated and relatively steady. Temperatures at intermediate depths demonstrated phase lag and amplitude decrement as compared to the ground-surface temperature fluctuations. Phase lag is defined as the delay in the timing of peak seasonal temperatures at a given depth in comparison to timing of corresponding peaks at the ground surface. The phase lag increased linearly with depth at the sites and had an approximate value of 26 days $/ \mathrm{m}$. Amplitude at a given depth is defined as one-half the maximum range of temperature measured over a 1 year period. The amplitude decrements were higher near the surface than at depth, and the amplitude decrement with depth ranged from approximately 3 to $7^{\circ} \mathrm{C} / \mathrm{m}$, with an average value of $5.2^{\circ} \mathrm{C} / \mathrm{m}$ (near the surface) to $0^{\circ} \mathrm{C} / \mathrm{m}$ (at depths greater than approximately 3 to $10 \mathrm{~m}$ ). The seasonal variations in temperatures decreased significantly within approximately 6 to $8 \mathrm{~m}$ depth from the top surfaces of the cells in the landfills. Examples of typical limiting temperature envelopes for the four sites are presented in Fig. 4. Normalized depth was used for comparison between the sites independent of the total depth of waste at a given site. The variability of temperatures decreased and the magnitude of temperatures increased with depth. Temperatures reached peak values at middle depths (normalized depths between 0.42 and 0.65 , Table 5) and then decreased to elevated yet lower values at the base of the cells (Fig. 4).

\section{Thermal Gradient}

A summary of the gradient data is provided in Table 6. The highest gradients were observed for the Michigan site and the lowest for the New Mexico site. In general, the gradients at each of the sites fluctuated between positive (downward heat flow) and negative (upward heat flow) near the surface in response to seasonal fluctuations, were zero at mid-depth, and were positive at great depths. The normalized depths for zero gradient indicate the rela- 


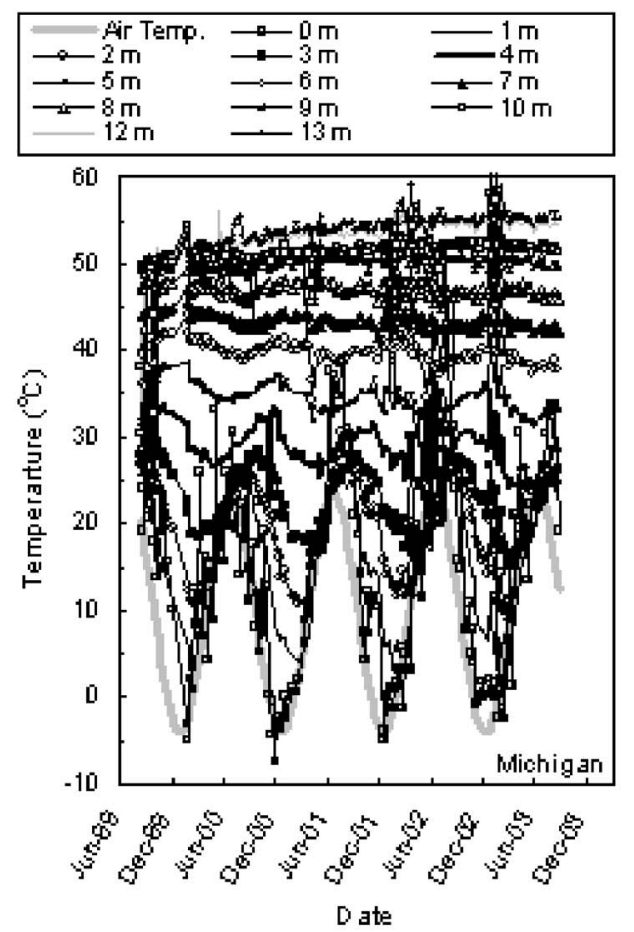

\begin{tabular}{|lll|}
\hline Air Temp. & $-0 \mathrm{~m}$ & $\longrightarrow 2 \mathrm{~m}$ \\
$\longrightarrow-4 \mathrm{~m}$ & $\longrightarrow 6 \mathrm{~m}$ & $-8 \mathrm{~m}$ \\
\hdashline $9 \mathrm{~m}$ & $\longrightarrow-10 \mathrm{~m}$ & $-11 \mathrm{~m}$ \\
\hline$-12 \mathrm{~m}$ & & \\
\hline
\end{tabular}
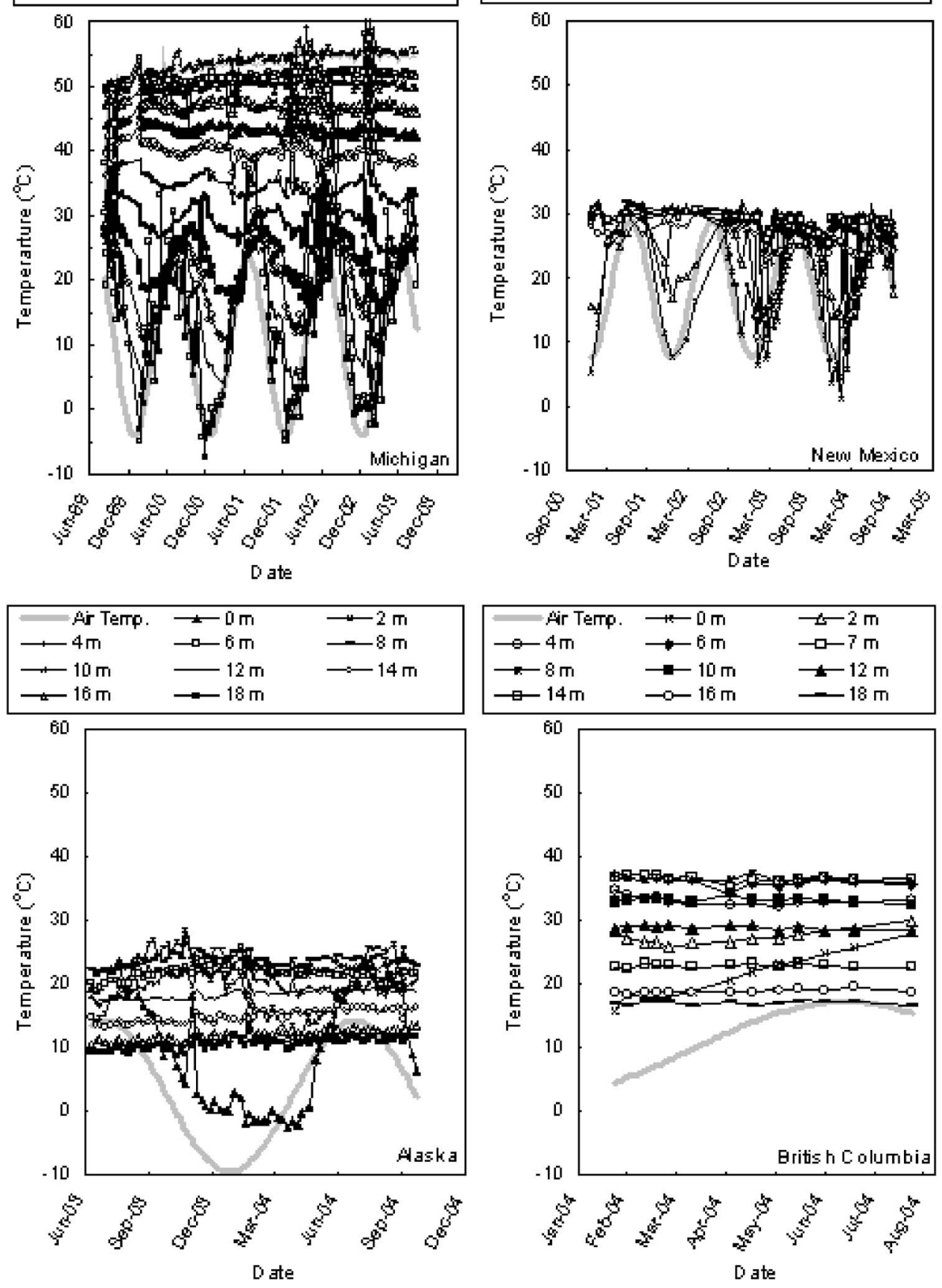

Fig. 3. Typical examples of variation of temperature with depth (vertical arrays)

tive locations of the origin of heat (i.e., locations of maximum stable temperatures). The average normalized depth for zero gradient from all cells at each site ranged from 0.35 (Alaska) to 0.50 (Michigan).

Typical examples of frequency distribution of gradients are provided in Fig. 5 based on data presented in Fig. 4. The percentages of measured gradients that exceed various threshold values for positive and negative gradients for a typical array are presented in Fig. 5(a), and examples of average absolute gradients that exceed various threshold values are provided in Fig. 5(b) for each site.

\section{Heat Content}

$H C$ was obtained using measurements from each sensor at the sites. Typical examples of the variation of $H C$ with depth for vertical arrays for each site are presented in Fig. 6. $H C$ increased to a peak value and then decreased to low values with depth at all of the sites and was greater toward the centers of the instrumented cells than at locations near the edges of the cells. Overall, the central core of the waste mass had high $H C$, whereas $H C$ was relatively low near the edges, top surfaces, and bases of the cells. The maximum $H C\left(47.8^{\circ} \mathrm{C}\right.$ day/day $)$ was observed in Michigan, 
Table 5. Maximum Stable Temperatures Measured Using Vertical Sensor Arrays

\begin{tabular}{lccc}
\hline \multicolumn{1}{c}{ Site } & $\begin{array}{c}\text { Maximum stable } \\
\text { temperature } \\
\left({ }^{\circ} \mathrm{C}\right)\end{array}$ & $\begin{array}{c}\text { Corresponding } \\
\text { waste age }\end{array}$ & $\begin{array}{c}\text { Corresponding } \\
\text { normalized depth }\end{array}$ \\
\hline Michigan & 56 & $5-7^{\mathrm{b}}$ & $0.42-0.61^{\mathrm{b}}$ \\
New Mexico & 32 & 5 & 0.45 \\
Alaska & 33 & 10 & 0.65 \\
British Columbia & 43 & 4 & 0.60
\end{tabular}

${ }^{\mathrm{a}} D_{S} / D_{t}$, where $D_{S}$ is depth of waste above sensor and $D_{t}$ is total depth of waste mass at location of sensor.

${ }^{\mathrm{b}}$ Same maximum stable temperature is observed in three cells at Michigan landfill.

followed by British Columbia $\left(44.0^{\circ} \mathrm{C}\right.$ day/day), Alaska $\left(26.9^{\circ} \mathrm{C}\right.$ day/day), and New Mexico $\left(12.5^{\circ} \mathrm{C}\right.$ day/day). The profiles of $H C$ were normalized with respect to total waste depth to evaluate the relative position of the peak $H C$ (Fig. 6). Analysis of all of the data from the sites indicated that peak $H C$ occurred at normalized depths of 0.43 (Michigan), 0.20 (British Columbia), 0.67 (Alaska), and 0.45 (New Mexico).

The effects of operational and climatic conditions on $H C$ were investigated. Type of waste was assumed to be similar at the sites and was not correlated with $H C$. The variations of $H C$ with initial waste temperature and waste placement rate are presented in

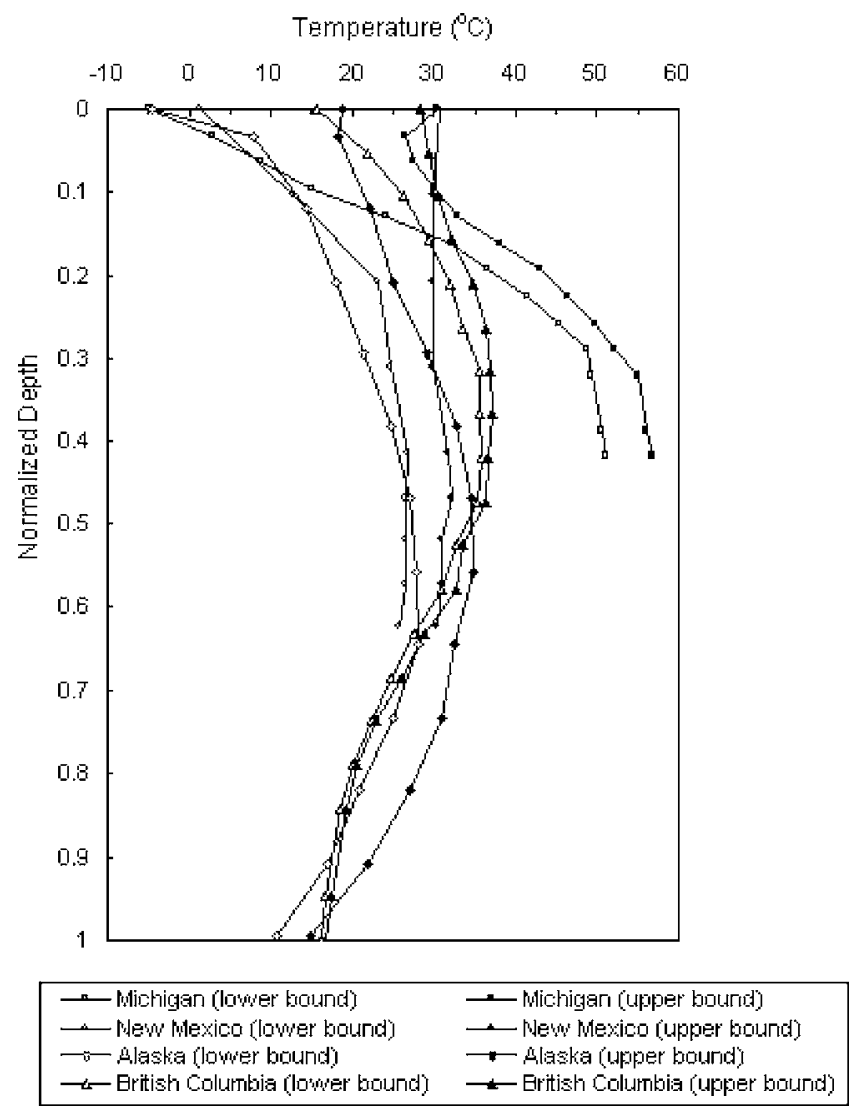

Fig. 4. Typical examples of temperature envelopes with depth
Table 6. Thermal Gradients

\begin{tabular}{|c|c|c|c|c|}
\hline Parameter & Michigan & New Mexico & Alaska & $\begin{array}{c}\text { British } \\
\text { Columbia }\end{array}$ \\
\hline $\begin{array}{l}\text { Average gradient } \\
\left({ }^{\circ} \mathrm{C} / \mathrm{m}\right)\end{array}$ & -0.79 & -0.52 & -0.1 & -0.14 \\
\hline $\begin{array}{l}\text { Measured range } \\
\left({ }^{\circ} \mathrm{C} / \mathrm{m}\right)\end{array}$ & $\begin{array}{l}-29.6 \text { to } \\
+27.1\end{array}$ & $\begin{array}{l}-13.9 \text { to } \\
+14.8\end{array}$ & $\begin{array}{l}-17.8 \text { to } \\
+22.0\end{array}$ & $\begin{array}{l}-12.5 \text { to } \\
+19.1\end{array}$ \\
\hline $\begin{array}{l}\text { Average absolute } \\
\text { gradient }\left({ }^{\circ} \mathrm{C} / \mathrm{m}\right)\end{array}$ & 2.20 & 1.24 & 1.88 & 1.89 \\
\hline $\begin{array}{l}\text { Absolute gradient } \\
\text { between } 0 \text { and } \\
5(\%)\end{array}$ & 87.5 & 95.5 & 91.0 & 94.9 \\
\hline $\begin{array}{l}\text { Absolute gradient } \\
\text { between } 5 \text { and } \\
10(\%)\end{array}$ & 10.86 & 4.22 & 6.55 & 4.40 \\
\hline $\begin{array}{l}\text { Absolute gradient } \\
\text { between } 10 \text { and } \\
20(\%)\end{array}$ & 1.55 & 0.24 & 2.43 & 0.69 \\
\hline $\begin{array}{l}\text { Absolute gradient } \\
\text { higher } \\
\text { than } \\
20(\%)\end{array}$ & 0.07 & 0 & 0 & 0 \\
\hline $\begin{array}{l}\text { Average } \\
\text { normalized } \\
\text { depth to zero } \\
\text { gradient }\end{array}$ & 0.50 & 0.49 & 0.35 & 0.49 \\
\hline
\end{tabular}

Fig. 7. $H C$ was directly correlated with initial waste temperature [Fig. 7(a)], and a strong linear correlation was observed between $H C$ and waste placement rate [Fig. 7(b)]

$$
H C=1.44548(w)+7.7033\left(\mathrm{R}^{2}=0.9724\right)
$$

where $H C$ is the heat content $\left({ }^{\circ} \mathrm{C}\right.$ day/day) and $w$ is the average waste placement rate $(\mathrm{m} /$ year $)$ for the range of waste placement rates between 4 and $24 \mathrm{~m} /$ year.

For climatic conditions, it was determined that average air temperature and mean annual earth temperature were not highly correlated with $H C$. The variation of average maximum $H C$ with average precipitation for each site is presented in Fig. 8. It was observed that $H C$ increased with precipitation up to a certain limit (peak $H C$ for Michigan site) and then decreased with further increases in precipitation. A strong linear correlation was observed between $H C$ and precipitation for the portion of data leading up to the peak $H C$ values for the New Mexico, Alaska, and Michigan data

$$
H C=18.977(P)-2.155\left(\mathrm{R}^{2}=0.9965\right)
$$

where $H C$ is the heat content $\left({ }^{\circ} \mathrm{C}\right.$ day/day) and $P$ is the average precipitation $(\mathrm{mm} /$ day) for the range between 0.6 and $2.3 \mathrm{~mm} /$ day.

The correlation between $H C$ and precipitation suggests that optimal precipitation conditions exist for production of heat in landfills, beyond which further addition of water does not contribute to heat generation. Even though Rowe (1998) identified leachate mounding as a main cause for heat generation in landfills, such an influence was not observed in this study. Leachate mounding was present only at the British Columbia site, which did not result in the maximum temperatures, $H C$, or heat generation (further described in the next section) observed in this study.

$H C$ was calculated for each calendar year period at each sensor location. The variation of maximum $H C$ with waste age for each array is presented in Fig. 9(a). In British Columbia, $H C$ increased 


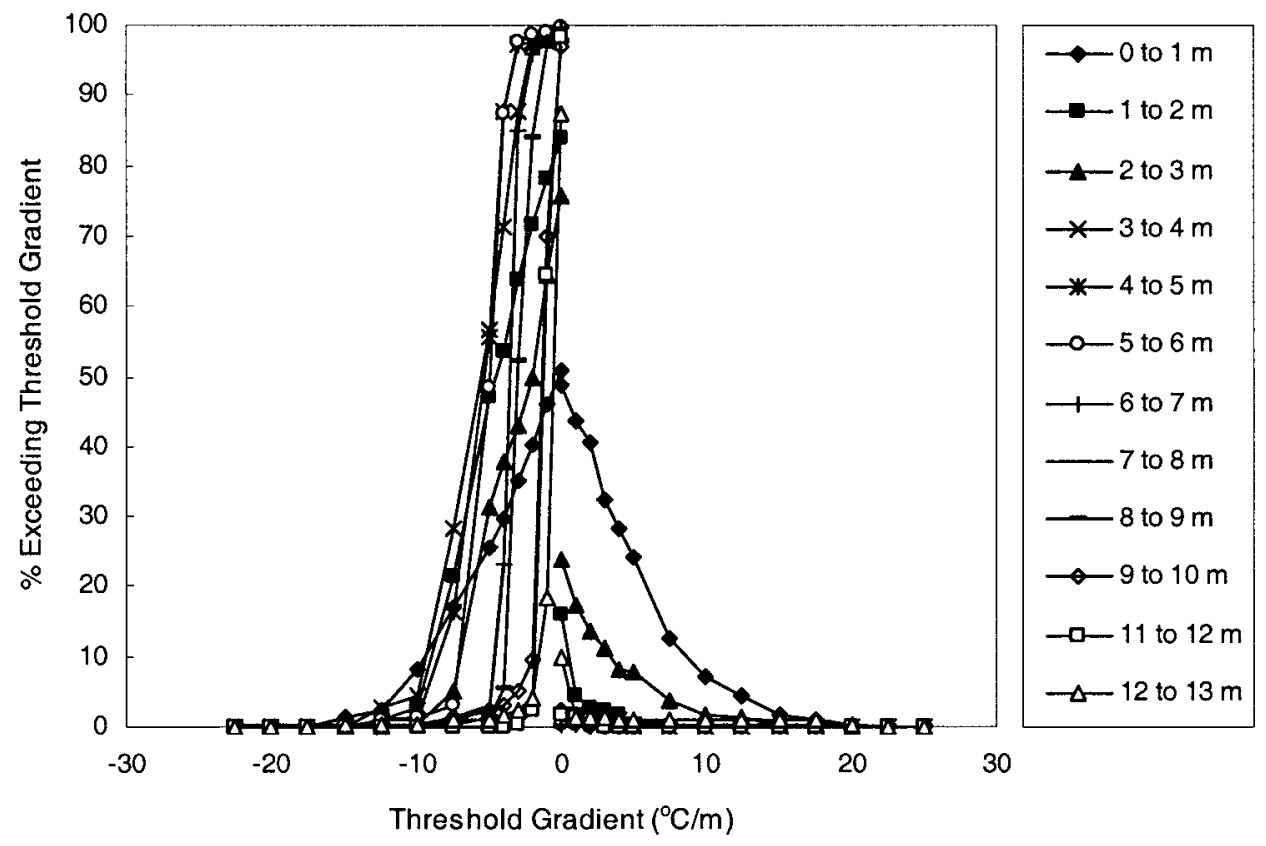

a) Typical Example of Measured Thermal Gradients

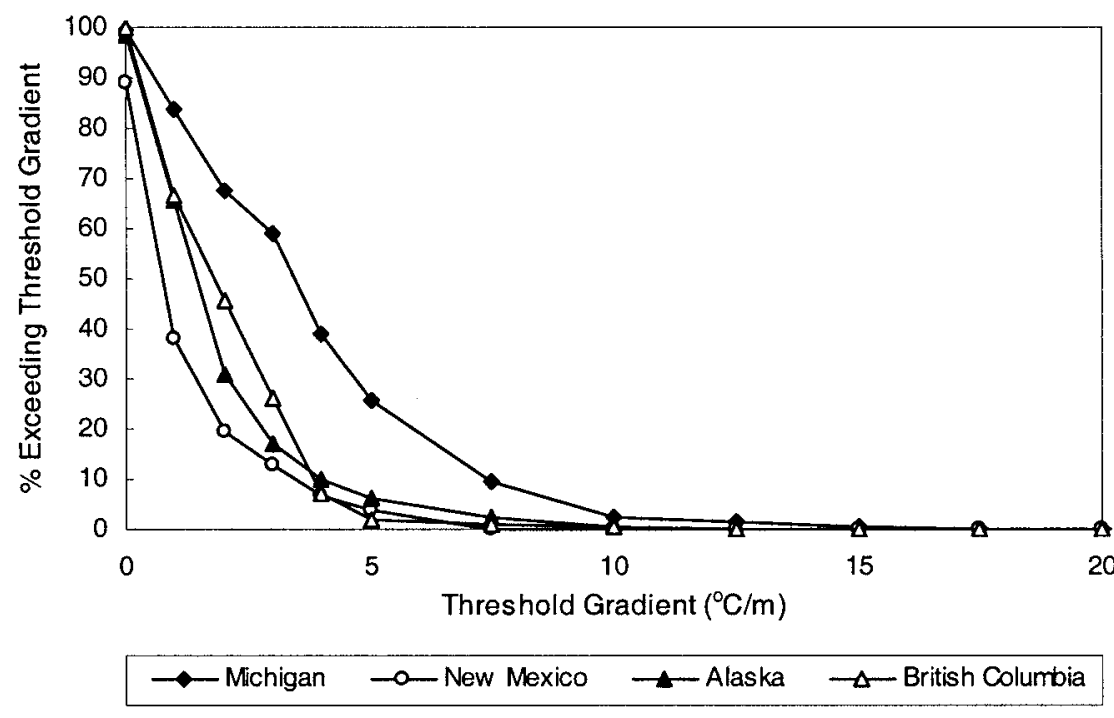

b) Typical Examples of Absolute Values of Thermal Gradients

Fig. 5. Frequency distribution of thermal gradients

rapidly to a peak value at 2 years, followed by a decrease to a stable low value that remained for the long term. At the Michigan site, $H C$ increased gradually to a peak value (at 4 years) and then decreased at a lower rate. A slow increase in $H C$ with waste age was observed in Alaska in comparison to the British Columbia and Michigan sites. Presence of a clear peak has not yet been observed in Alaska. Data from New Mexico indicate relatively low constant $H C$ with waste age. Overall, it was observed that high precipitation caused rapid decomposition, resulting in rapid development and high values of $H C$, whereas low precipitation caused slow decomposition, resulting in slow development and low values of $H C$ (Figs. 8 and 9).

A new formulation was developed to describe the relationship between heat content and time for landfills using common exponential growth and decay functions. In particular, an equation in the form of the Streeter Phelps approach (Vesilind 1997) was adopted for modeling heat content with time for wastes in this study:

$$
H C=\frac{a \psi}{(b-a)}\left(e^{-a t_{w}}-e^{-b t_{w}}\right)
$$

where $H C=$ heat content $\left({ }^{\circ} \mathrm{C}\right.$ day/day); $a=$ heat generation constant $\left(\right.$ day $\left.^{-1}\right) ; b=$ heat utilization constant $\left(\right.$ day $\left.^{-1}\right) ; t_{w}=$ waste age (year); and $\psi=$ heat production potential $\left({ }^{\circ} \mathrm{C}\right.$ day/day).

The model curve fits generated for the study sites using Eq. (5) are presented in Fig. 9(a). The model curve fits generated using a least-squares analysis visually appeared to represent the measured data adequately. The aptness of the model was further verified using a residuals analysis (Devore 2004). The analysis indicated 


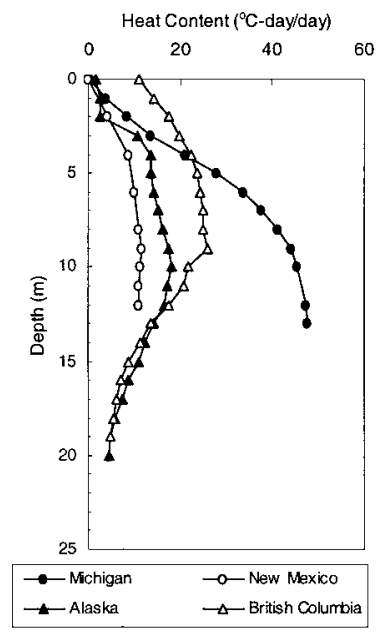

a) Actual Depths

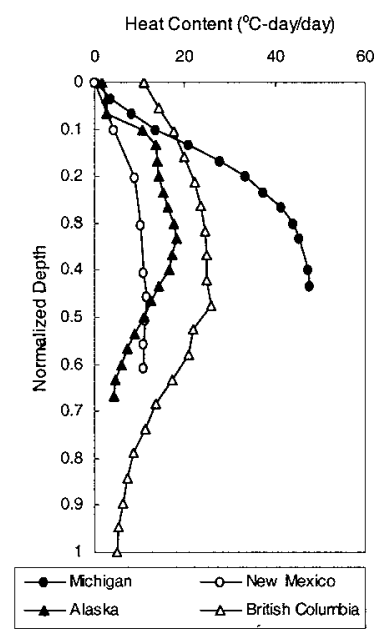

b) Normalized Depths

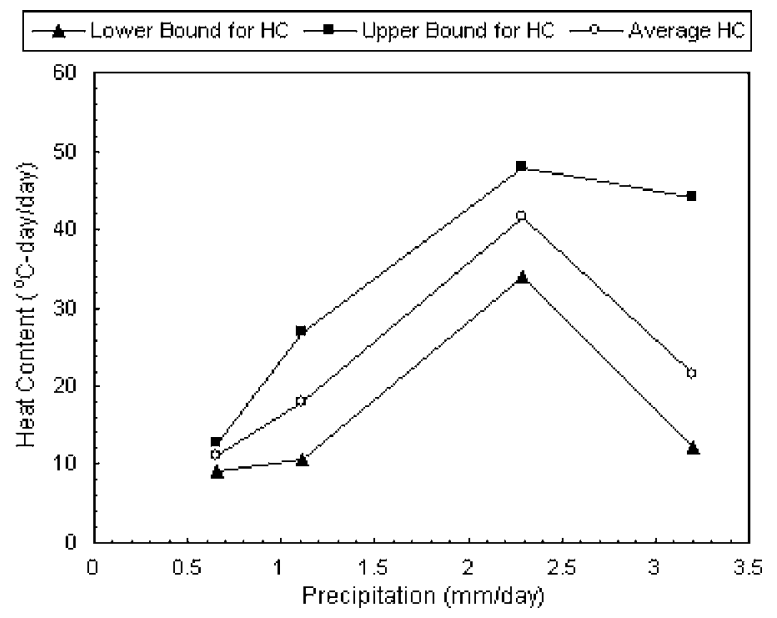

Fig. 8. Variation of $H C$ with average precipitation

Fig. 6. $H C$ versus depth for vertical arrays

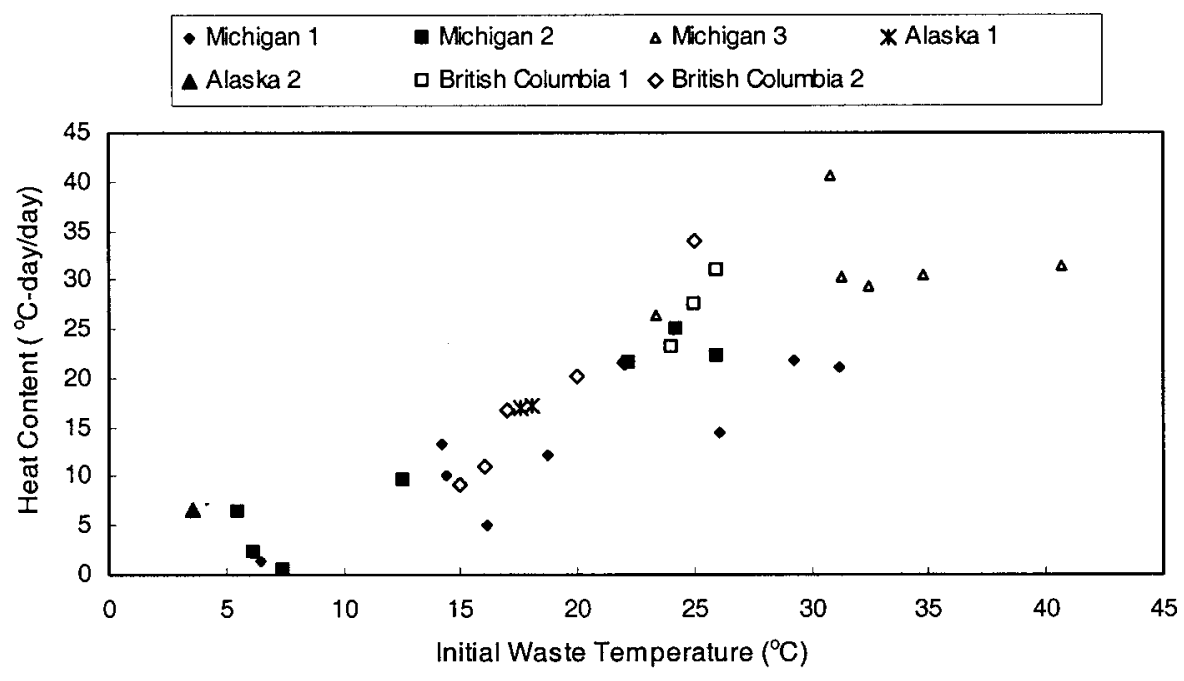

a) Variation of $H C$ with Initial Waste Temperature (Horizontal Arrays)

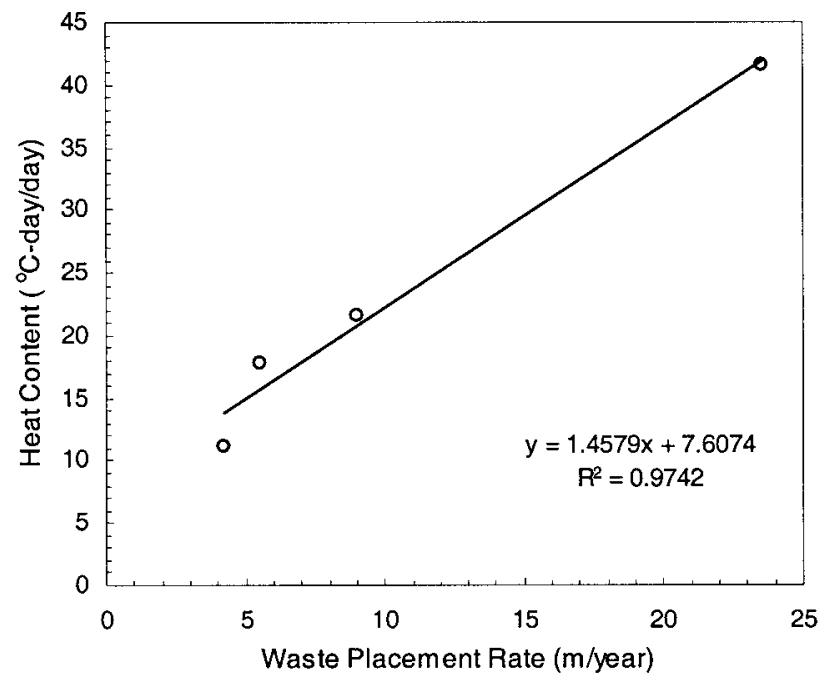

b) Variation of $H C$ with Waste Placement Rate

Fig. 7. Variation of $H C$ with operational conditions 


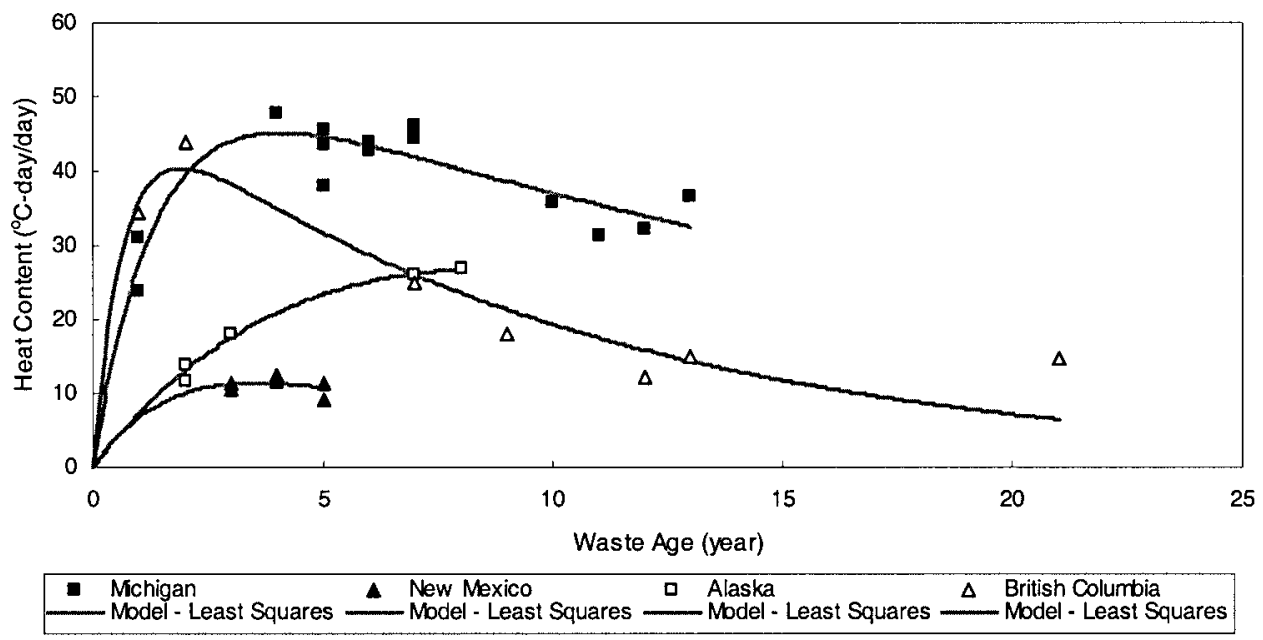

(a) Data from Current Investigation

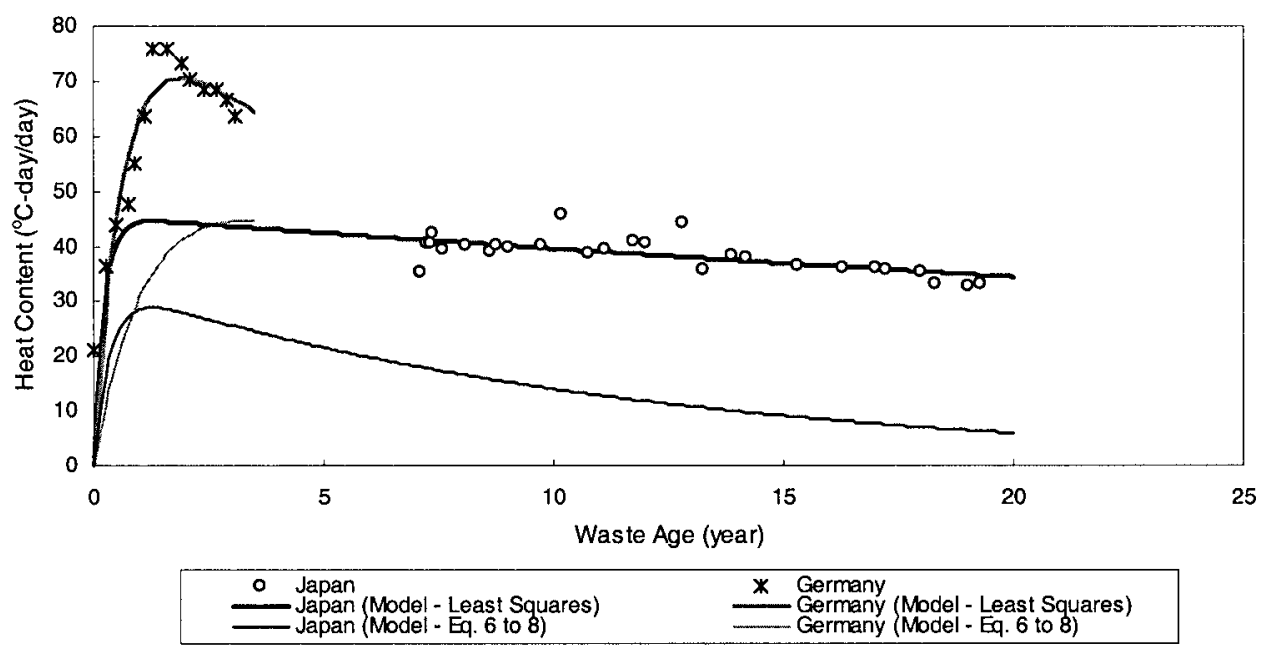

(b) Model Validation

Fig. 9. Variation of maximum $H C$ with waste age

that the residuals had near normal distribution with no discernible unusual patterns, and therefore the model was appropriate for the four data sets.

The parameters $a, b$, and $\psi$ from the curve fits were correlated with operational and climatic conditions at the sites. It was determined that $a$ varied with precipitation, $b$ varied with waste placement rate, and $\psi$ varied with $a$ using a nonlinear optimization algorithm. As expected, the same parameters (waste placement rate and precipitation) had significant effects on measured $H C$ and model parameters used in prediction of $H C$. The values for $a$ were between 0.15 and $1.5 \mathrm{day}^{-1}$, the values for $b$ were between 0.04 and $0.40 \mathrm{day}^{-1}$, and the values for $\psi$ were between 49 and $55^{\circ} \mathrm{C}$ day/day for the sites. The predictive equations for the model parameters are presented below:

$$
a=1.64 \times 10^{-6}(p)^{2}-0.0008(p)+0.2326
$$

$$
b=0.8496 e^{-0.9938(w)}
$$

$$
\psi=-3.0123(a)^{2}+0.6472(a)+54.9243
$$

where $p=$ average precipitation ( $\mathrm{mm} /$ year); and $w=$ waste placement rate (m/year).

An analysis was conducted to validate the model using data from two landfills with long-term temperature data. Temperature data for the bases of a landfill in Japan and a landfill in Germany were presented in Yoshida and Rowe (2003). Additional data for the site in Japan were provided in Yoshida et al. (1997) and Rowe (1998), which were all incorporated in the validation analysis. The base temperatures were converted to maximum waste temperatures using correlations provided in Yoshida and Rowe (2003). HCs were determined using the climatic conditions at the sites. The original data, Eq. (5) curve fits generated using a leastsquares analysis, and Eq. (5) curve fits generated by obtaining the model parameters using Eqs. (6) to (8) are presented in Fig. 9(b). The original data and least-squares model fits indicate that the form of Eq. (5) is generally applicable to these data sets, whereas the curve fits generated using model parameters [Eqs. (6) to (8)] underestimate the measured data. 


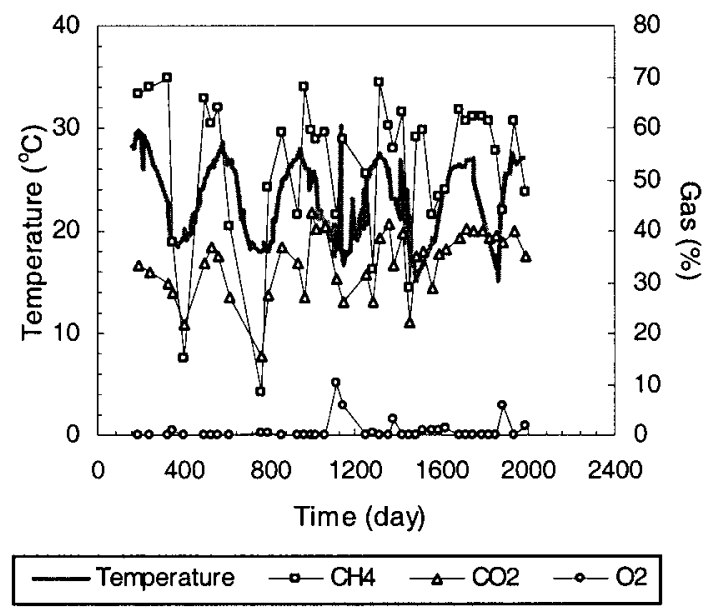

a) Seasonal Fluctuation of Temperature and Gas at Shallow Depth

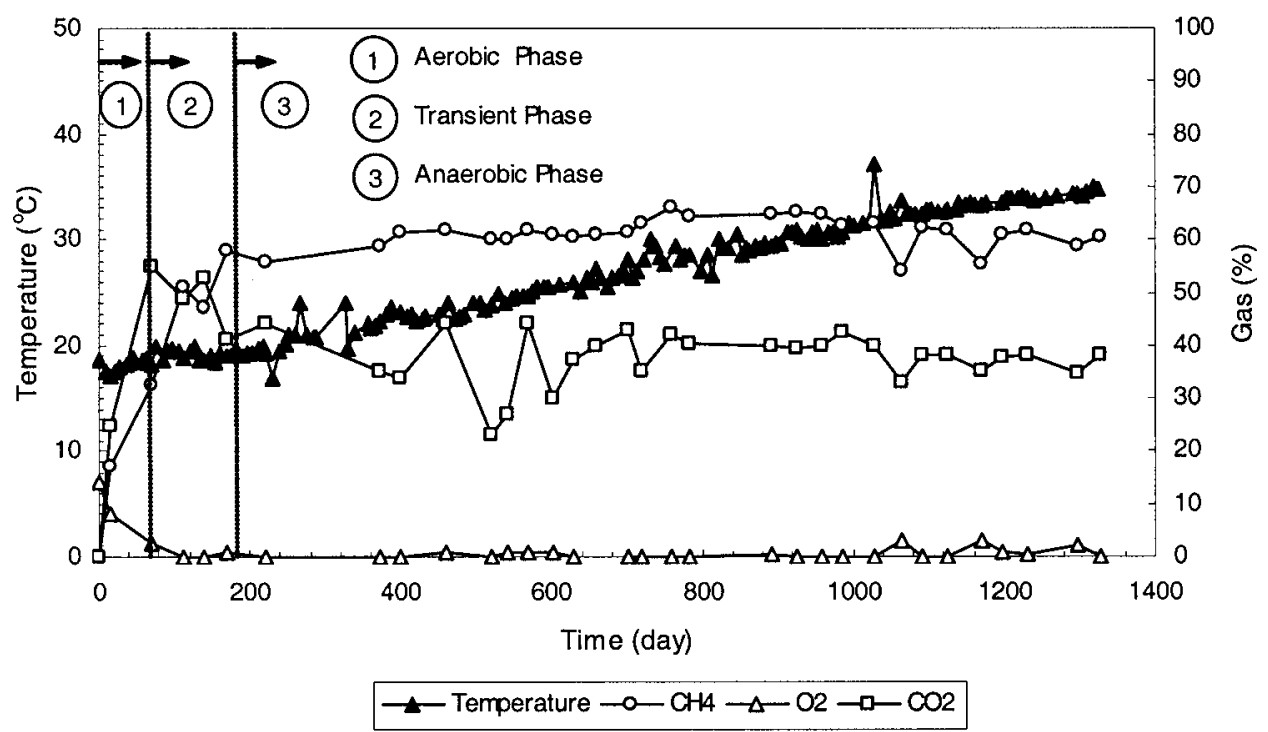

b) Stable Temperature and Gas Trends at Depth

Fig. 10. Variation of temperature and gas with time

This validation process is highly approximate as the conditions at the sites in Japan and Germany have significant differences from the sites in North America: the landfill in Germany contained bottom ash and the landfill in Japan contained highly organic wastes; frequencies of temperature data were relatively low in Japan and Germany; data for Japan were available starting only after an approximate waste age of 7 years; and the waste filling rate was not available for Germany. While the general form of the proposed equation is appropriate for predicting $\mathrm{HC}$ as a function of waste age, further verification for the proposed model is required using comparable comprehensive data sets.

\section{Heat Generation}

The heat generation, $E$, calculated using Eq. (2) varied between 23 and $77 \mathrm{MJ} / \mathrm{m}^{3}$ at the sites. The maximum heat generation was observed in Michigan, followed by (in decreasing order) British Columbia, Alaska, and New Mexico. Significant variation in $E$ was observed due to waste age, similar to variation of $H C$ with age. In general, the timing for peak $E$ was similar to timing for peak $H C$.

The conductive thermal losses to the surrounding environment were estimated to be between 42 and $139 \mathrm{MJ} / \mathrm{m}^{3}$-year for losses toward the cover (upward losses) and either between 9 and $48 \mathrm{MJ} / \mathrm{m}^{3}$ - year for losses toward the subgrade at mean annual earth temperature or between 6 and $52 \mathrm{MJ} / \mathrm{m}^{3}$-year for losses toward the liner at a steady elevated temperature (downward losses). The convective thermal losses were estimated to be between 0 and $11 \mathrm{MJ} / \mathrm{m}^{3}$ - year, and the maximum values were calculated for the British Columbia site with the highest amount of leachate. The conductive losses were observed to be significantly higher than the convective losses. $E$ varied between 71 and $279 \mathrm{MJ} / \mathrm{m}^{3}$ at the sites when thermal losses were included for a 1 year steady-state period of analysis. Overall, the heat generation values both with and without thermal losses were lower than val- 
ues from incineration analyses and were generally higher than the heat generation obtained from biochemical prediction models (Table 1).

\section{Waste Decomposition Conditions During Heat Generation}

Typical plots of variation of temperature and oxygen, methane, and carbon dioxide with time are presented in Fig. 10. Methane and carbon dioxide concentrations vary with seasonal fluctuations similar to variation of temperatures at shallow depths [Fig. 10(a)], whereas three distinct phases for gas composition were observed for wastes located at depth [Fig. 10(b)]. Initially, the fresh wastes contained air (approximately 20\% $\mathrm{O}_{2}$ ). Composition of the gas changed over time, where the oxygen concentrations decreased to zero and methane and carbon dioxide concentrations started to increase. A peak is typically observed in $\mathrm{CO}_{2}$ concentration during this period. Subsequent to this period, the $\mathrm{CH}_{4}$ and $\mathrm{CO}_{2}$ concentrations stabilized at approximately 60 and $40 \%$, respectively.

The end of the aerobic period was identified as depletion of $\mathrm{O}_{2}$ (concentrations decreasing to approximately $0 \%$ ); the beginning of the stable anaerobic period was identified by the onset of relatively stable $\mathrm{CH}_{4}$ and $\mathrm{CO}_{2}$ concentrations; and the transition phase occurred between these periods. The aerobic phase occurred generally over durations of approximately a few weeks to 3 months. The duration of the transition period generally ranged from 2 to more than 5 months, with peak $\mathrm{CO}_{2}$ concentrations occurring at approximately 1 to 3 months (with few exceptions between 3 and 4 months) subsequent to waste placement in a cell. The stable anaerobic phase started 5 to 6 months subsequent to waste placement and is the predominant gas phase in the cells.

Overall, temperatures of wastes continued to increase during aerobic, transition, and stable anaerobic phases of decomposition (Fig. 10). The trend of early temperature peaks in the aerobic phase, followed by decreases in temperatures during the anaerobic phase as reported in some studies (Farquhar and Rovers 1973; Zanetti et al. 1997; Lefebvre et al. 2000), was not observed in this study. Seasonal variations, such as those presented in Fig. 10(a), may have affected the analysis of data at shallow depths in the studies reported in the literature. Sustained high temperatures were measured in wastes under anaerobic conditions.

Temperature increase and $H C$ were determined and compared for the various decomposition phases. The cumulative transition and stable anaerobic phases were termed postaerobic phase for this analysis. It was determined that the temperature increase in the postaerobic period was 5 to 10 times more than the temperature increase in the aerobic period. The amount of temperature increase that occurred in the wastes during aerobic decomposition was approximately 20 to $30 \%$ of the total increase in the temperature of wastes. The heat content in the postaerobic period was 1.1 to 2.6 times more than the heat content in the aerobic period. The temperature trends and the relative proportions of temperature increase and heat content during various phases of decomposition were generally similar at the other study sites.

\section{Summary and Conclusions}

This study was conducted to extensively investigate heat generation in landfills on a field scale, including the variation of temperatures, rate of temperature changes, thermal gradients, and heat generation capacity as a function of operational conditions and climatic region. Data were collected at four landfills located in North America (Michigan, New Mexico, Alaska, and British Columbia), and spatial and temporal distributions of waste temperatures were determined over monitoring periods varying from 9 months to more than 5 years.

Temperatures of wastes at shallow depths (6 to $8 \mathrm{~m}$ depth) and near edges of cells (within approximately $20 \mathrm{~m}$ ) conform to seasonal variations, whereas steady elevated temperatures (23 to $57^{\circ} \mathrm{C}$ ) are reached at depth and at central locations. Temperatures decrease from the elevated levels near the base of landfills, yet remain higher than ground temperatures. Thermal gradients were in the range of approximately -30 to $+22^{\circ} \mathrm{C} / \mathrm{m}$, with average absolute values typically less than $5^{\circ} \mathrm{C} / \mathrm{m}$.

Heat content of wastes was determined as the difference between measured waste temperatures and unheated baseline waste temperatures at equivalent depths. Peak $H C$ s were in the range of 12.5 to $47.8^{\circ} \mathrm{C}$ day/day and were directly correlated with waste placement rates and initial waste temperatures. The peak $H C$ occurred at an optimal average precipitation $(2.3 \mathrm{~mm} /$ day $)$, beyond which $H C$ decreased. High precipitation caused rapid decomposition, resulting in rapid development and high values of $H C$, whereas low precipitation caused slow decomposition, resulting in slow development and low values of $H C$. Precipitation provided a direct indication of moisture conditions of wastes since water management practices (e.g., stormwater management, interim cover configuration) were similar at the four sites. An exponential growth and decay formulation was used to model $H C$ as a function of climatic and operational conditions.

Heat generation was determined using $H C$ in $1 \mathrm{D}$ heat transfer analysis. The calculated heat generation values $\left(23\right.$ to $77 \mathrm{MJ} / \mathrm{m}^{3}$ without losses and 71 to $279 \mathrm{MJ} / \mathrm{m}^{3}$ with losses for a period of 1 year) were significantly higher than biochemical prediction models, yet lower than values from incineration analyses. The highest values for temperatures, gradients, $H C$, and heat generation were observed for the Michigan site, followed by (in decreasing order) the British Columbia, Alaska, and New Mexico sites. Temperature increases and $H C$ values were greater during anaerobic decomposition than aerobic decomposition. Sustained high temperatures were measured in wastes under postaerobic conditions, which started within a few weeks to 3 months subsequent to waste placement.

Overall, it was determined that significant amounts of heat are generated in landfills, resulting in long-term elevated waste temperatures. The elevated temperatures should be considered in analysis of decomposition of wastes as well as in the determination of physical, geomechanical, and hydraulic properties and behavior of wastes. The elevated temperatures and their effects on geotechnical properties of wastes are expected to be significant for conventional and even more so for bioreactor landfills.

\section{Acknowledgments}

This study has been supported by the National Science Foundation (GOALI grant number CMS-9813248, SGER grant number CMS-0301032, and a 2004 AAAS/NSF WISC grant). The assistance of the partner landfills (Sauk Trail Hills Development, Corralitos Regional Landfill, Anchorage Regional Landfill, and Vancouver Landfill) is greatly appreciated.

\section{References}

Attal, A., Akunna, J., Camacho, P., Salmon, P., and Paris, I. (1992). "Anaerobic degradation of municipal wastes in landfill." Water Sci. 
Technol. 25(7), 243-253.

Cecchi, F., Pavan, P., Musacco, A., Mata-Alvarez, J., and Vallini, G. (1993). "Digesting the organic fraction of municipal solid waste: Moving from mesophilic $\left(37^{\circ} \mathrm{C}\right)$ to thermophilic $\left(55^{\circ} \mathrm{C}\right)$ conditions," Waste Manage. Res., 11, 403-414.

Dach, J., and Jager, J. (1995). "Prediction of gas and temperature with the disposal of pretreated residential waste." Proc., 5th Int. Waste Management and Landfill Symp., T. H. Christensen et al., eds., Vol. I, CISA, Italy, 665-677.

Davies, T. W. (2004). "Estimated average gross calorific values." Univ. of Exeter, Dept. of Engineering, Exeter, U.K. 〈http://www .ex.ac.uk/ TWDavies/energy_conversion/calorific\%20values\%20of\% 20fuels.htm>, November 23, 2004.

Devore, J. L. (2004). Probability and statistics for engineering and the sciences, 6th Ed., Brooks Cole, Pacific Grove, Calif.

DeWalle, F. B., Chian, E. S. K., and Hammerberg, E. (1978). "Gas production from solid waste in landfills." J. Environ. Eng. Div. (Am. Soc. Civ. Eng.), 104, (EE3), 415-432.

El Fadel, M., Findikakis, A. N., and Leckie, J. O. (1996). "Numerical modelling of generation and transport of gas and heat in sanitary landfills. I: Model formulation." Waste Manage. Res., 14(5), 483-504.

Farquhar, G. J., and Rovers, F. A. (1973). "Gas production during refuse decomposition." Water, Air, Soil Pollut., 2(4), 483-495.

Gartung, E., Mullner, B., and Defregger, F. (1999). "Performance of compacted clay liners at the base of municipal landfills: The Bavarian experience." Proc., 7th Int. Waste Management and Landfill Symp., T. H. Christensen, et al. eds., Vol. III, CISA, Italy, 31-38.

Gibbs, A. (2004). Gasification as an option for municipal waste, Cardiff Foundation of Environmental Research, Cardiff Univ. School of Engineering, Cardiff, Wales〈http://www.cfer.info.〉 (November 16, 2004).

Hanson, J. L., Edil, T. B., and Yesiller, N. (2000). "Thermal properties of high water contnt materials." ASTM Special Technical Publication 1374, Geotechnics of high water content materials, T. B. Edil and P. J. Fox, eds., ASTM, West Conshohocken, Pa., 137-151.

Hartz, K. E., Klink, R. E., and Ham, R. K. (1982). "Temperature effects: methane generation from landfill samples." J. Environ. Eng. Div. (Am. Soc. Civ. Eng.), 108(4), 629-638.

Houi, D., Paul, E., and Couturier, C. (1997). "Heat and mass transfer in landfills and biogas recovery." Proc., 6th Int. Waste Management and Landfill Symp., T. H. Christensen et al., eds., Vol. I, CISA, Italy, 101-108.

Koerner, G. (2001). "In situ temperature monitoring of geosynthetics used in a landfill." Geotechnical Fabrics Rep. 19(4), 12-13.

Lamothe, D., and Edgers, L., (1994). "The effects of environmental parameters on the laboratory compression of refuse." Proc., 17th Int. Madison Waste Conf., Dept. of Engineering Professional Development, Univ. of Wisconsin, Madison, Wisc., 592-604.

Landsberg, H. E., Lippmann, H., Paffen, K. H., and Troll, C. (1966). World maps of climatology, 3rd Ed., E. Rodenwaldt and H. J. Jusatz, eds., Springer, Berlin.

Lefebvre, X., Lanini, S., and Houi, D. (2000). "The role of aerobic activity on refuse temperature rise. I: Landfill experimental study." Waste Manage. Res., 18(5), 444-452.

Mata-Alvarez, J., and Martinez-Viturtia, A. (1986). "Laboratory simula- tion of municipal solid waste fermentation with leachate recycle." J. Chem. Technol. Biotechnol., 36(12), 547-556.

Meteorological Service of Canada (MSC. (2004). Climate database. $<$ http://www.msc-smc.ec.gc.ca/contents e.html $>$ (November 23, 2004).

Mitchell, J. K. (1993). Fundamentals of soil behavior, 2nd Ed., Wiley, New York.

National Climatic Data Center (NCDC. (2004). Climate database. $<$ http://www.ncdc.noaa.gov/> (June 1, 2004).

Oak Ridge National Laboratory (ORNL. (1981). "Regional analysis of ground and above-ground climate." Rep. No. ORNL/Sub-81/40451/1, U.S. Dept. of Energy, Office of Buildings Energy R\&D, Oak Ridge, Tenn.

Pirt, S. J. (1978). "Aerobic and anaerobic microbial digestion in waste reclamation." J Appl. Chemistry and Biotechnology., 28, 232-236.

Rees, J. F. (1980a). "Optimisation of methane production and refuse decomposition in landfills by temperature control," J. Chem. Technol. Biotechnol., Society of Chemical Industry, 30(8), 458-465.

Rees, J. F. (1980b). "The fate of carbon compounds in the landfill disposal of organic matter," J. Chem. Tech. Biotechnol., Society of Chemical Industry, 30(4), 161-175.

Rowe, R. K. (1998). "Geosynthetics and the minimization of contaminant migration through barrier systems beneath solid waste." Proc., 6th Int. Conf. on Geosynthetics, R. K. Rowe, ed., Vol. I, IFAI, Atlanta, 27-102.

Swiss Federal Office of Energy (SFOE. (2004). "Calorific value of energy resources." < <http://www.energie-schweiz.ch/internet/00735/ index.html?lang $=\mathrm{en}>$ (November 23, 2004).

Tchobanoglous, G., Theisen, H., and Vigil, S. A. (1993). Integrated solid waste management: Engineering principles and management issues, McGraw-Hill, New York.

Townsend, T. G., Miller, W. L., Lee, H. J., and Earle, J. F. K. (1996). "Acceleration of landfill stabilization using leachate recycle." J. Environ. Eng. 122(4), 263-268.

U.S. Environmental Protection Agency (USEPA. (2003). Municipal solid waste in the United States: 2001 facts and figures executive summary, EPA530-S-011, Office of Solid Waste and Emergency Response.

Vesilind, P. A. (1997). Introduction to environmental engineering, PWS Publishing, Boston.

Yesiller, N., and Hanson, J. L. (2003). "Analysis of temperatures at a municipal solid waste landfill." Proc., 9th Int. Waste Management and Landfill Symp., T. H. Christensen et al., eds., CISA, Italy.

Yoshida, H., and Rowe, R. K. (2003). "Consideration of landfill liner temperature." Proc., 9th Int. Waste Management and Landfill Symp., T. H. Christensen et al., eds., CISA, Italy.

Yoshida, H., Tanaka, N., and Hozumi, H. (1997). "Theoretical study on heat transport phenomena in a sanitary landfill," Proc., 6th Int. Waste Management and Landfill Symp., T. H. Christensen et al., eds., Vol. I, CISA, Italy 109-120.

Young, A. (1992). "Application of computer modelling to landfill processes." DoE Rep. No. CWM 039A/92, Dept. of Environment, London.

Zanetti, M. C., Manna, L., and Genon, G. (1997). "Biogas production Evaluation by Means of Thermal Balances." Proc., 6th Int. Waste Management and Landfill Symp., T. H. Christensen et al., eds., Vol. II, CISA, Italy, 523-531. 